\title{
The Evolution of Molecular Recognition: From Antibodies to Molecularly Imprinted Polymers (MIPs) as Artificial Counterpart
}

\author{
Ortensia Ilaria Parisi ${ }^{1,2,+}{ }^{\mathbb{D}}$, Fabrizio Francomano ${ }^{1,+}$, Marco Dattilo ${ }^{1}$, Francesco Patitucci ${ }^{1}$, Sabrina Prete ${ }^{1}$, \\ Fabio Amone ${ }^{2}$ and Francesco Puoci $1,2, *$ D
}

1 Department of Pharmacy, Health and Nutritional Sciences, University of Calabria, 87036 Rende (CS), Italy; ortensiailaria.parisi@unical.it (O.I.P.); fabriziofrancomano@libero.it (F.F.); marco.dattilo@unical.it (M.D.); francesco.patitucci@unical.it (F.P.); sabrina.prt@email.it (S.P.)

2 Macrofarm s.r.l., c/o Department of Pharmacy, Health and Nutritional Sciences, University of Calabria, 87036 Rende (CS), Italy; amonefabio@gmail.com

* Correspondence: francesco.puoci@unical.it; Tel.: + 39-0984-493151

+ These authors contributed equally to this work.

check for updates

Citation: Parisi, O.I.; Francomano, F.; Dattilo, M.; Patitucci, F.; Prete, S.;

Amone, F.; Puoci, F. The Evolution of Molecular Recognition: From Antibodies to Molecularly Imprinted Polymers (MIPs) as Artificial Counterpart. J. Funct. Biomater. 2022, 13, 12. https://doi.org/10.3390/ jfb13010012

Academic Editor: Richard Hoogenboom

Received: 14 December 2021

Accepted: 26 January 2022

Published: 28 January 2022

Publisher's Note: MDPI stays neutral with regard to jurisdictional claims in published maps and institutional affiliations.

Copyright: (C) 2022 by the authors. Licensee MDPI, Basel, Switzerland. This article is an open access article distributed under the terms and conditions of the Creative Commons Attribution (CC BY) license (https:// creativecommons.org/licenses/by/ $4.0 /)$.

\begin{abstract}
Molecular recognition is a useful property shared by various molecules, such as antibodies, aptamers and molecularly imprinted polymers (MIPs). It allows these molecules to be potentially involved in many applications including biological and pharmaceutical research, diagnostics, theranostics, therapy and drug delivery. Antibodies, naturally produced by plasma cells, have been exploited for this purpose, but they present noticeable drawbacks, above all production cost and time. Therefore, several research studies for similar applications have been carried out about MIPs and the main studies are reported in this review. MIPs, indeed, are more versatile and cost-effective than conventional antibodies, but the lack of toxicity studies and their scarce use for practical applications, make it that further investigations on this kind of molecules need to be conducted.
\end{abstract}

Keywords: molecular imprinting; molecularly imprinted polymers (MIPs); antibodies; synthetic antibodies; polymeric antibodies; plastic antibodies; theranostics; diagnostics; therapeutics; drug delivery systems (DDSs)

\section{Introduction}

Molecular recognition is a desired ability for molecules involved in various technological applications, in particular in the field of life sciences. Molecules with this property, indeed, are able to selectively bind compounds with biological importance (biomarkers such as microorganisms' proteins and toxins, proteins and metabolites expressed in particular pathological conditions including cancer and autoimmune diseases), mainly for diagnostic, theranostic, pharmacological, drug delivery and research uses. Molecules of this type are present in nature, such as antibodies, which are normally produced by immune cells. Natural antibodies were extracted from cells and the production process was increasingly controlled and refined. Antibodies were used for many applications, but, in the last decades, different kinds of molecules of synthetic origin were designed to replace them.

This review is about molecules with molecular recognition capabilities, starting from antibodies and focusing on the more recent molecularly imprinted polymers (MIPs), deepening their design, synthesis and applications.

\section{Antibodies}

In 1891 Paul Ehrlich used the term antibody referring to proteins present in animal extracellular fluids (mainly in the blood) with an important role in specific immune responses [1]. Antibodies (also called immunoglobulins) are glycoproteins, whose primary 
role consists in the recognition of foreign substances (such as microorganisms components), called antigens, directly neutralising them or binding them for successive processing by other elements of the immune system [2]. These macromolecules, produced by plasma cells, which originate from B lymphocytes [3], are Y-shaped globular proteins formed by two light chains and two heavy chains, held together by disulphide bonds [4]. A schematic representation of antibodies structure is shown in Figure 1.

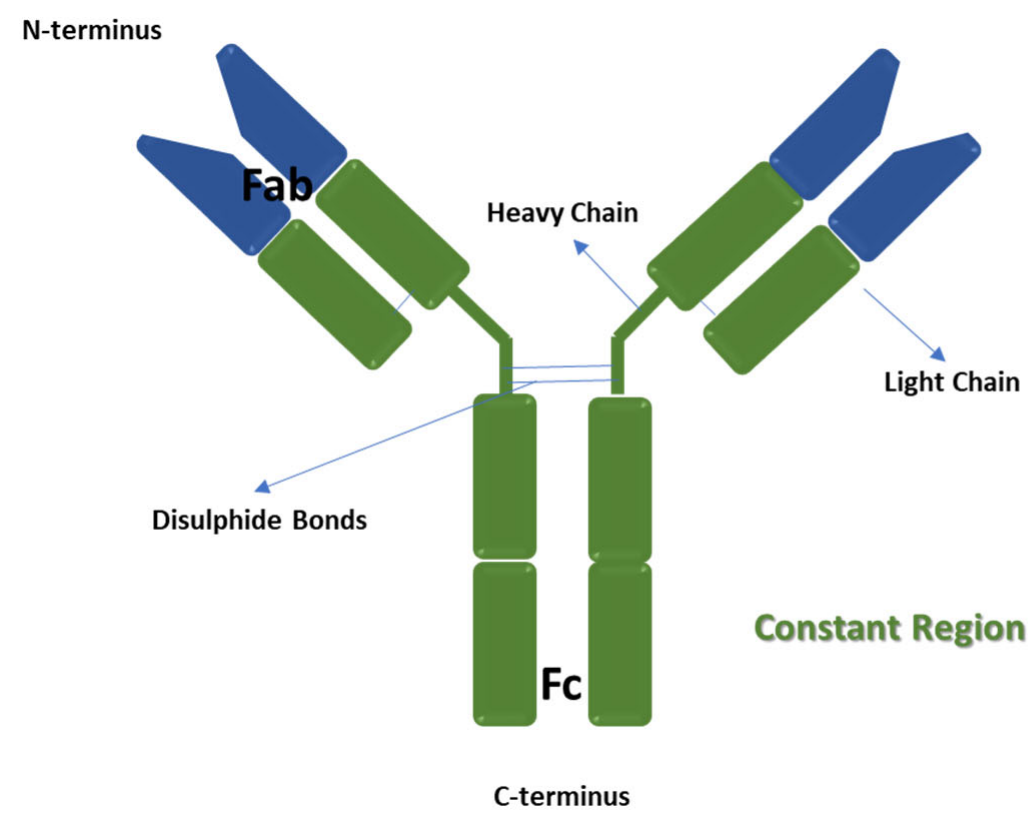

Variable Region

Figure 1. Schematic representation of the antibodies structure.

There are five classes of antibodies, which differ for the type of heavy chain and, consequently, for their function and localisation in the organism: $\operatorname{IgA}$, IgD, IgE, IgG and IgM [5]. All the chains contain one N-terminal variable domain. The light chains are formed of one constant domain, whereas the heavy chains are made up of three or four constant domains. In detail, the heavy chains with three constant domains contain a hinge region between the first and the second domains [5]. An antibody contains the antigen-binding fragment $(F a b)$ region, formed of the N-terminal end of both light and heavy chains, and the crystallisable fragment $(F c)$ region, which allows the interaction with the immune system cells or molecules [6].

In 1952, Richard J. Goldberg described the interaction antigen-antibody (Figure 2), assessing that each antibody is capable to bind only to a specific antigen [7]. The interaction antigen-antibody is achieved between the epitope (a specific portion of the antigen) and the paratope (a specific portion of the antibody) [8]. Antigen and the relative antibody are bound through weak and non-covalent interactions, like Van der Waals forces, hydrogen bonds, hydrophobic and electrostatic interactions, resulting in a relatively stable bond [9]. The interaction between antigen and antibody is called agglutination and it is characterized by high specificity and affinity, resulting in the formation of an antigen-antibody complex that is a reversible reaction, hence there is a dynamic equilibrium between the complex and the dissociated form. The strength of the binding is expressed as avidity [10]. 


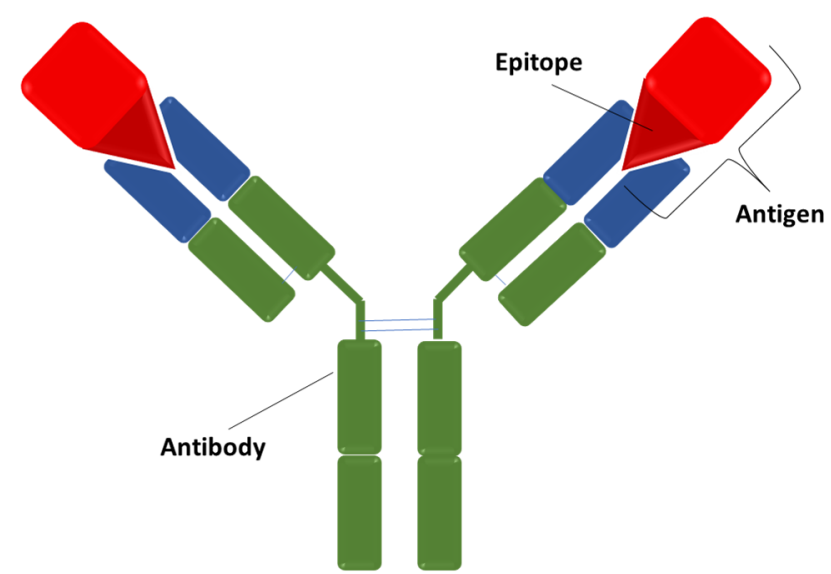

Figure 2. Interaction antigen-antibody. The ratio antigen/antibody is 2:1.

\subsection{Antibodies Applications}

The interaction antigen-antibody, or rather, molecular recognition made antibodies useful tools for many purposes. They are used for basic research, drug delivery, diagnostic, therapeutic and theranostic applications [11]. Antibodies (both monoclonal and polyclonal ones and their fragments) are daily used in cellular biology, molecular biology, biochemistry and medical research, in particular in the form of immunoassays, which are frequently employed for diagnostic use also, as well as for analytical applications in general [12] In detail, antibodies or their fragments (single-domain antibodies or heavy chain-only antibodies) [13] are used in antibody conjugated signal generation systems for immunoassays. When an antibody binds to its target, label materials, linked to the macromolecules, emit a signal to quantify the entity of the binding of the antibody to its target. Label materials are usually radioactive isotopes [14] or enzymes, such as alkaline phosphatase and horseradish peroxidase [15], which form coloured, fluorescent or chemiluminescent products [16]. Examples of immunoassays are Western blotting [17], ELISA (enzyme-linked immunosorbent assay) [18], flow cytometry [19], surface enhanced Raman scattering (SERS) based immunoassay [20], Förster resonance energy transfer (FRET) immunoassays [21]. Furthermore, in immunoprecipitation, the measurement of the binding antibody-target is achieved directly on the complex, which precipitates [22]. In addition, lateral flow immunoassays (LFIAs), also called lateral flow immunochromatographic assays, are designed in order to detect the presence or absence of a specific analyte in the sample [23]. Immunoassays are used for the diagnosis of many diseases, retracing biomarkers, for example for cancer, but also other analytic purposes such as the detection of environmental pollutants and food contaminants [12].

Antibodies find application also in bioimaging techniques, such as magnetic resonance imaging (MRI), used, above all, for detecting cancer and fluorescence imaging [24]. Antibodies (or fragments) conjugates allow to enhance the ability of these techniques to discern between normal and cancer cells [25].

Furthermore, antibodies have been coupled to PCR (polymerase chain reaction) in order to increase the accuracy of this technique, avoiding the nonspecific amplification of undesired DNA sequences by Taq polymerase at low temperature [26] and, in the case of antibodies with enzymatic activities (called abzymes), to catalyse reactions [27].

In the last decades, theranostics has been developed from the combination of diagnosis and therapy $[28,29]$. Antibodies (or fragments) conjugated with nanomaterials have found many theranostic applications, in particular for cancer diagnosis and treatment [30], thanks to the ability to selectively accumulate in target tissues [31]. Theranostic antibodies have been developed for photoacoustic imaging and thermal ablation of gastric cancer cells [32] or for the imaging and treating of breast cancer cells [33]. Another example is provided by Webb et al. [34], who designed a conjugate for photothermal ablation of triple-negative breast cancer cells and SERS imaging of immunomarkers. 
From a purely therapeutic point of view, the first monoclonal antibody with a therapeutic indication, approved in 1986, was the immunosuppressant muromonab-CD3 [35], which consists of a murine monoclonal antibody against T cell-expressed CD3 [36]. The first monoclonal antibody with an oncologic indication was rituximab, a chimeric anti-CD20 IgG1 approved for non-Hodgkin's lymphoma in 1997 by US Food and Drug Administration (FDA) [35,37].

Polyclonal antibodies possess less suitable characteristics for therapeutic use, thus, their applications are limited to transplant rejection and few pathologies [38].

Nowadays, hundreds of monoclonal antibodies (or their fragments) and their conjugates have been studied in clinical trials and tens out of these have been approved as treatments for various diseases $[35,39,40]$ :

- cancer (lymphoma, myeloma, melanoma, glioblastoma, neuroblastoma, sarcoma, colorectal, lung, breast, ovarian, head and neck cancers) [35,40,41];

- $\quad$ autoimmune diseases (arthritis, ankylosing spondylitis, psoriasis, multiple sclerosis, systemic lupus erythematosus) [42];

- $\quad$ inflammatory diseases (Crohn's disease, asthma [43], Muckle-Wells syndrome [44], inflammations of the airways, skin and gastrointestinal tract) [35];

- $\quad$ infectious diseases (anthrax infection [45], prevention of Clostridium difficile infection recurrence [46], mycosis [47]);

- $\quad$ other conditions (migraine [48], transplant rejection [38], osteoporosis [49], high cholesterol plasmatic levels [50]).

Finally, antibodies have been physically or chemically [51,52] conjugated to nanosized drug delivery systems $[53,54]$ due to their molecular recognition properties.

There are many studies in literature in which nanoparticles, often of magnetic type, linked to antibodies were preferentially accumulated in tumour cells than in the other tissues [55] resulting in a specific action of the active ingredients and avoiding their interaction with normal cells.

\subsection{Antibodies Production}

Monoclonal antibodies are produced by plasma cells, are identical to each other and are able to recognize a specific antigen [35]. In 1975, Köhler and Milstein devised the hybridoma technique, which allows the quantitative production of pure monoclonal antibodies [56]. This technique consists in collecting spleen cells from mice that have been injected with the antigen, which triggers the immune response. After that, cells are fused to immortal myeloma cells originating the hybridoma, a cell line that indeterminately produces monoclonal antibodies against the specific antigen [56]. In order to increase monoclonal antibodies' efficacy and duration, in the 1990s chimeric (by combining sequences of the murine variable domain with human constant region domain) [57] and humanized (through complementary-determining region grafting technique in which non-human antibody CDR sequences are transplanted into a human framework sequence in order to maintain target specificity) [58] antibodies were developed. Moreover, fully-human antibodies were produced through antibody phage display which is a genetic engineering technique in which RNA is collected from human B lymphocytes to create a cDNA library using reverse transcriptase enzyme. Then, the library is inserted in the bacteriophage, which infects bacteria that, in turn, produce human antibodies [59].

Polyclonal antibodies, instead, are produced by different cell lines, have a different amino acid sequence and recognize different epitopes of the same antigen. In order to produce polyclonal antibodies, animals are injected with the antigen; when the antibodies are formed, animal blood is extracted and purified to collect polyclonal antibodies [60]. Polyclonal antibodies are more stable and tolerant to changes in the antigen than the monoclonal ones and their production is easier and less expensive than the one necessary for preparing monoclonal antibodies, but several disadvantages need to be considered such as intra-batch variability, low specificity and a high degree of cross-reactivity [60]. 
However, both monoclonal and polyclonal antibodies need animals to be kept, which requires costs, care and qualified personnel, in order to be produced. Furthermore, the fact that it is necessary to wait for the animal immune response makes the production time longer.

\subsection{Alternatives to Antibodies}

Antibodies revealed themselves as very useful, but they have some limits, in particular monoclonal antibodies, which are the most used ones. The most relevant of these limits is the lack of reproducibility and the consequent antibody variability [61]. In fact, genetic drift is unavoidable after a long period of time spent from the first generation of hybridoma cells [62]. Moreover, monoclonal antibodies are rarely characterised and many preparations may be contaminated by nonspecific immunoglobulins from the host animal [63] requiring repeated validation for every new batch [64], particularly when antibodies are employed in methods that demand high sensitivity. Therefore, various alternative technologies with the same ability of molecular recognition, also called antibody mimetics, which are better in terms of properties, versatility and, above all, production costs and time, have been developed.

Aptamer technology is one of the main substitutes for antibodies. An aptamer is generally a molecule of nucleic acid (either DNA or RNA), but sometimes it can be a small peptide [65]. Aptamers are characterized by the same property as antibodies to bind molecules, mainly proteins, so these molecules are called chemical antibodies [62]. Aptamers were first isolated in 1990 and are chemically synthesized. In detail, they are generated in vitro following the SELEX (systematic evolution of ligands by exponential enrichment) method [66], which is a high throughput screening process. Aptamer sequence is defined, so, contrary to antibodies, a specific aptamer can be easily chemically reproduced avoiding variability issues [67]. Furthermore, the way in which aptamers are obtained is more costeffective, rapid and easy to apply than antibody production. For all these reasons, aptamers may potentially be employed for all the applications in which antibodies are involved. In fact, nowadays, they could find applications in imaging, sensing, diagnostic, drug delivery, therapeutic, theranostic and analytical applications [68-71], even if this technology has still been less explored than antibodies and several challenges are associated with aptamers including cross-reactivity and poor specificity.

Other significant examples of substitutes of antibodies are provided by:

- $\quad$ affibodies (protein scaffolds), which are the result of protein engineering: they consist of a scaffold protein, made up of the $\mathrm{IgG}$ of a bacterial protein, on which a three-helix protein is inserted [62,72];

- $\quad$ RGD peptides, which are cyclic peptides formed of three amino acids, such as arginine, glycine and aspartic acid (RGD), and are used in drug delivery systems combined with active molecules for imaging [73], tissue repair [74] and tumour therapy [75], because of their ability to bind integrins in the extracellular matrix [74];

- small organic molecules, such as folic acid, which are conjugated to diagnostic and therapeutic agents in order to localise these molecules preferentially in cancer tissues, where the folic acid receptor is overexpressed [76].

Finally, molecularly imprinted polymers (MIPs) are the most studied antibody mimetics and the focus of this review [77].

\section{Molecularly Imprinted Polymers (MIPs)}

MIPs are polymeric matrices with the ability to selectively bind specific molecules. The molecular imprinting technique consists of the polymerization of monomers in the presence of a target molecule, which acts as a template during the synthesis of the polymer. The resulting products have an affinity similar to the affinity antibody-antigen, achieved through the formation of sites that are complementary to the template molecule. Molecular imprinting was first introduced in 1931 by Polyakov [78], who noticed that, when polymerization to get silica was conducted with benzene, the resulting silica showed unusual adsorption properties toward the additive. The scientist explained this evidence in terms 
of silica pore in polymeric structure. In 1949 Dickey [79] reported the same synthesis achieved by Polyakov, but the additional substance, in this case, was the dye methyl orange and the obtained silica was selective for this molecule. Dickey repeated the procedure using other dyes with similar results. After Dickey's method, many chemists prepared specific silica-based sorbents with the same strategy; however, the interest in imprinted silica waned for the scarce stability and reproducibility of the materials. A great impulse to the development of molecular imprinting was given by Wulff and Sarhan [80], who, in 1972, introduced the covalent approach, and, above all, Mosbach, who, in the 1980s [81], devised the non-covalent approach.

To date, a lot of in vitro and in vivo studies have been carried out on MIPs, which will be deepened in the review.

\subsection{MIPs Synthesis}

MIPs synthesis process (Figure 3) can be divided into three main phases:

- pre-polymerization, in which the template and the functional monomers form a complex;

- $\quad$ polymerization, in which monomers polymerize in the presence of the template and the cross-linking agent;

- $\quad$ the template removal [77].

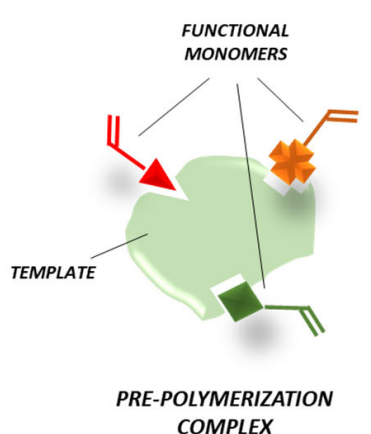

COMPLEX

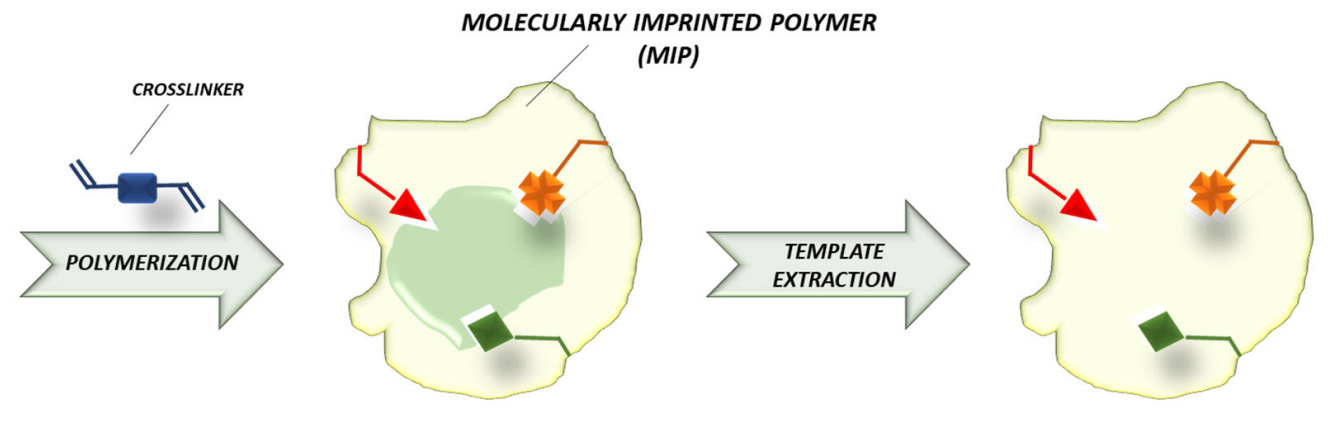

Figure 3. Molecular imprinting mechanism.

The result is a stable polymer that is ready for the rebinding of the target molecule and whose characteristics (rigidity, porosity, molecular weight, resistance in different conditions and responsivity to various stimuli) can be modulated [77,82]. There are two main approaches in molecular imprinting relying on the nature of the interactions that form the pre-polymerization complex.

The covalent approach is based on reversible covalent bonds between template molecules and functional monomers. After polymerization, the template is removed from the polymeric matrix by chemical cleavage of the corresponding covalent bonds $[77,83,84]$. The greatest pro of the covalent approach lies in the strength of covalent interactions, determining a uniform distribution of the recognition sites and reducing the nonspecific interactions. The limits of this approach include the difficulty in obtaining a thermodynamic equilibrium [85], because of the strength of the covalent bonds, and, consequently, the possibility to recognize only a few target molecules [82], such as alcohols, aldehydes, ketones, amines and carboxylic acids [77].

The non-covalent approach, instead, is based on the formation of relatively weak non-covalent interactions between template and functional monomers, such as hydrogen bonds, ionic interactions, van der Waals forces and dipole-dipole interactions both during the polymerization and the rebinding phase [85]. This approach presents many advantages that make it preferable in comparison to the covalent one. In detail, non-covalent imprinting is characterized by the simplicity of the procedure and the possibility to use various monomers (methacrylic acid [86], 4-vinylbenzoic acid [87], acrylamide [88], vinyl 
pyrrolidone [89], 2-hydroxyethyl methacrylate [90], etc.) and to target a wide spectrum of molecules [77,91-93]. The disadvantages of the non-covalent approach are the request of a large excess of functional monomer, due to the need to shift the equilibrium toward the associated form of the pre-polymerization complex, and the formation of non-selective binding sites [77].

Starting from covalent and non-covalent approaches, Whitcombe devised the intermediate semi-covalent approach [94], in which the pre-polymerization interactions between the template and the functional monomers are covalent, whereas the rebinding step is characterized by non-covalent interactions. This approach allows to combine the high affinity in the formation of the pre-polymerization complex with the rapid binding kinetics in the rebinding phase $[91,95]$.

There are many factors that need to be considered for the synthesis of MIPs such as the nature of functional monomers, crosslinking agents and initiators, the solvents, the ratio among the reagents, the polymerization technique and the imprinting approach $[77,85]$. The structures of some monomers used in molecular imprinting are reported in Figure 4.<smiles>C=CC(=O)O</smiles>

ACRYLIC ACID<smiles>C=C(C)C(=O)O</smiles>

METHACRYLIC ACID<smiles>C=Cc1ccncc1</smiles>

4-VINYLPYRIDINE<smiles>C=CN1CCCC1=O</smiles>

VINYL PYRROLIDONE<smiles>C=CC(N)=O</smiles>

ACRYLAMIDE<smiles>C=Cc1ccc(C(=O)O)cc1</smiles>

4-VINYLBENZOIC ACID

Figure 4. Chemical structure of some of the monomers used for MIPs synthesis.

Many polymerization techniques have been used for the synthesis of MIPs (Table 1).

The most classic method is free radical polymerization, which requires heat or light to activate the process [96]. Several monomers are suitable for this technique, but this strategy leads to the formation of high-branched, atactic MIPs with low binding specificity and selectivity [97], due to the inability to control propagation and termination phases, and a high polydispersity index [96]. This is the reason why controlled radical polymerization started to be preferred to free radical polymerization [98], because it is a more versatile group of reversible deactivation radical polymerization techniques (atom transfer radical polymerization [99], reversible addition-fragmentation chain transfer [100], nitroxide-mediated polymerization [101], iniferter-mediated polymerization [102]) that allow to control molecular weight distribution and stereochemistry, but not the size of the synthesized nanoparticles. Nowadays, the most frequently used techniques, specific for the synthesis of nanoMIPs, include precipitation polymerization, emulsion polymerization and core-shell polymerization with subsequent grafting [103-106]. 
Precipitation polymerization (Figure 5) was reported for the first time by Ye et al. in 1999 [107]. It is a simple method that allows the synthesis of uniform and spherical MIP nanoparticles in a single-step reaction. The method involves an excess of solvent, in which the monomers, the initiator and the template are soluble, whereas the polymer that will be formed is not. The formation of polymer chains from monomers and oligomers continues until their size makes them precipitate $[103,108]$. The obtained MIPs are collected by washing and centrifugation [109]. Important parameters to be modulated are solvent polarity, temperature and stirring. The pros of this technique are that it is not necessary to use any stabilizer molecules, whereas the cons are the need to use a high amount of template and the long time required [103,110].
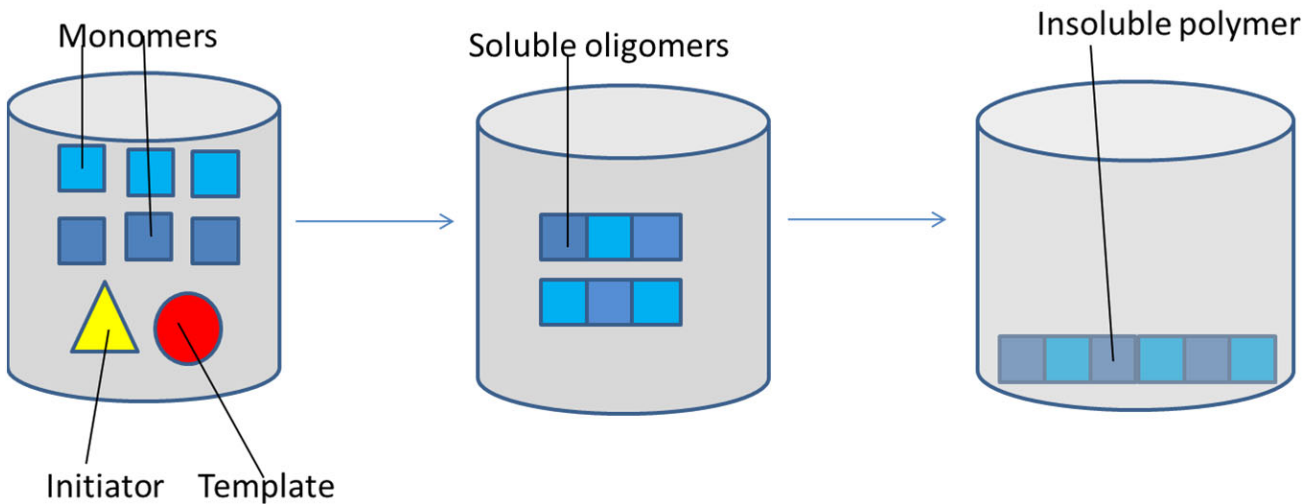

Figure 5. Precipitation polymerization: monomers, template and initiator are soluble; the chain grows until its size makes it insoluble, making the polymer precipitates.

Another important technique exploited for the production of nanoMIPs is emulsion polymerization (Figure 6) that enables the synthesis of monodispersed MIP nanoparticles [73] containing surface-exposed binding sites [111]. The polymerization process usually occurs in oil-in-water emulsions (less frequently also in water-in-oil emulsions) in the presence of a surfactant [112]. This technique can be performed in the form of mini- and micro-emulsion polymerization, obtaining nanoparticles of respectively $30-500 \mathrm{~nm}$ and $5-50 \mathrm{~nm}$ diameter [103]. A co-surfactant stabilizes the monomers, then homogenization is carried out by sonication or stirring [113]; the difference between mini- and micro-emulsion polymerization is that the latter requires higher surfactant concentration to get smaller particles. An advantage of emulsion polymerization is the high yield and the suitability to protein imprinting [73], but the obtained polymers often require purification, above all to remove the surfactant, with consequent waste of time [103].
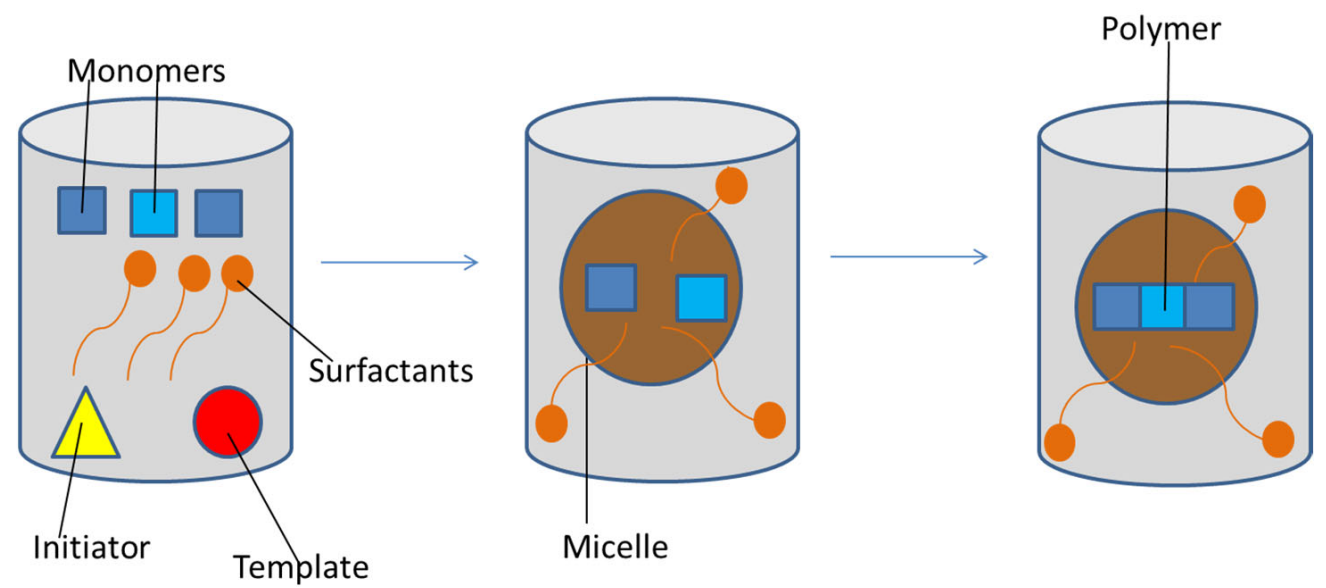

Figure 6. Emulsion polymerization: monomers are included in micelles with surfactants on their surface; the polymerization occurs inside the micelles. 
Furthermore, a technique to produce core-shell MIP nanoparticles is core-shell grafting followed by polymerization (Figure 7) [103]. Preformed particles that compose the core, such as organic polymers [114], silica [115], superparamagnetic iron oxides [116], quantum dots [117], upconversion nanophosphors [118], carbon dots [119], and gold/silver particles [120], are linked to MIPs, which represent the shell of the nanoparticles. This technique allows fine control over MIP size [121].
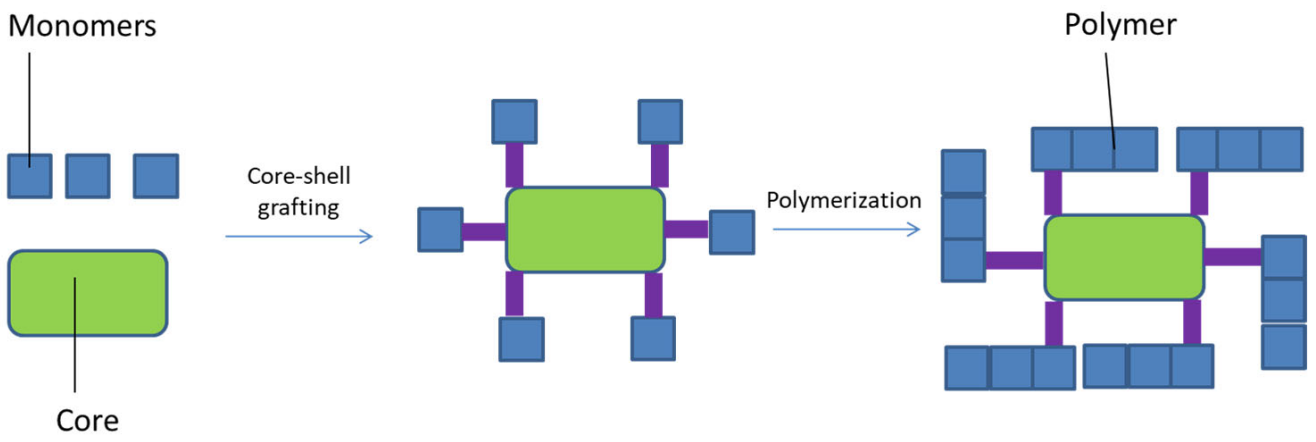

Figure 7. Core-shell grafting followed by polymerization.

The solid-phase approach (Figure 8) is one of the most recent devised techniques for nanoMIPs synthesis, which consists of the polymerization following the immobilization of the template molecule on glass beads activated in $\mathrm{NaOH}$ to expose $-\mathrm{OH}$ groups for the silanization [122]. After that, nanoMIPs need to be purified. With solid-phase synthesis, it is possible to synthesize MIPs with very high affinity and homogeneous distribution of the recognition sites, to recycle the template and avoid the washing phase for the removal of the template from the polymer $[103,111]$. On the other hand, the limits of this technique are the low yield and the fact that it is not very effective for templates with big structures [111].

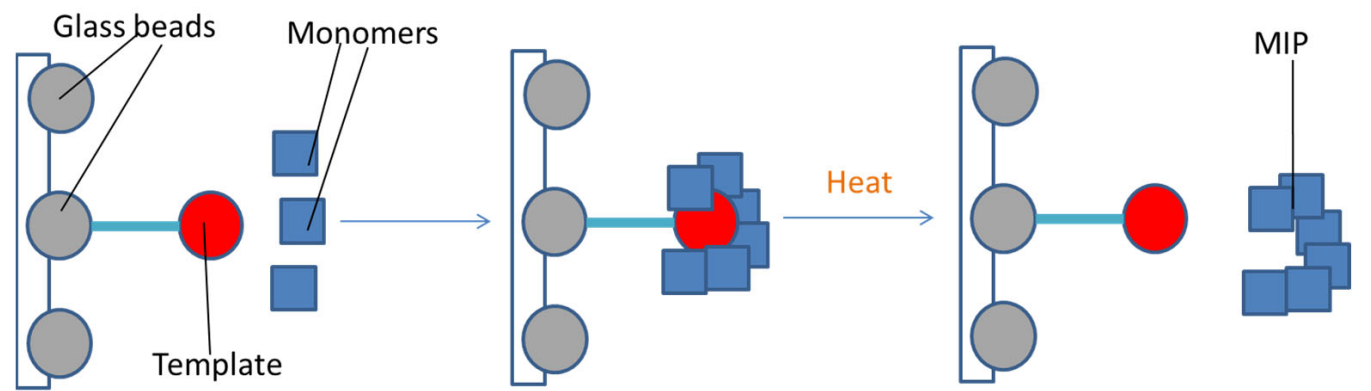

Figure 8. Solid-phase approach: the polymerization occurs around the template immobilized on glass beads; the detachment is obtained by heat.

Moreover, the detachment of the MIPs is conducted applying heat, which makes it impossible to increase the reaction yield by performing multiple syntheses on the same solid phase with thermosensitive templates like proteins [123].

Finally, high dilution polymerization is a method in which the monomer is dissolved in a high amount of solvent in order to avoid precipitation during the process [124]. This technique allows the synthesis of MIPs of a few nm, like natural antibodies size [125]. 
Table 1. Techniques for the synthesis of MIPs.

\begin{tabular}{|c|c|c|c|}
\hline Technique (Ref.) & Mechanism & Pros & Cons \\
\hline $\begin{array}{c}\text { Free radical } \\
\text { polymerization [96] }\end{array}$ & $\begin{array}{c}\text { Free radical } \\
\text { polymerization triggered by } \\
\text { heat or light }\end{array}$ & $\begin{array}{l}\text { Ease; wide choice of } \\
\text { monomers }\end{array}$ & $\begin{array}{l}\text { Low binding specificity and } \\
\text { selectivity }\end{array}$ \\
\hline $\begin{array}{c}\text { Controlled radical } \\
\text { polymerization [98-102] }\end{array}$ & $\begin{array}{l}\text { Deactivation radical } \\
\text { polymerization }\end{array}$ & $\begin{array}{l}\text { Control of molecular weight } \\
\text { distribution and } \\
\text { stereochemistry }\end{array}$ & $\begin{array}{c}\text { Lack of control of the } \\
\text { nanoparticles size; } \\
\text { high vulnerability to } \\
\text { impurities and moisture; } \\
\text { limited range of suitable } \\
\text { monomers; not all vinyl } \\
\text { monomers can be } \\
\text { polymerized by ATRP (atom } \\
\text { transfer radical } \\
\text { polymerization); } \\
\text { NMP (nitroxide-mediated } \\
\text { radical polymerization) has } \\
\text { been applied only once in the } \\
\text { imprinting field due to the } \\
\text { high required temperatures } \\
\text { and the impossibility of using } \\
\text { methacrylates }\end{array}$ \\
\hline
\end{tabular}

\begin{tabular}{|c|c|c|c|}
\hline $\begin{array}{c}\text { Precipitation } \\
\text { polymerization [107] }\end{array}$ & $\begin{array}{l}\text { The formation of polymer } \\
\text { chains from monomers and } \\
\text { oligomers continues until } \\
\text { their size makes them } \\
\text { precipitate }\end{array}$ & $\begin{array}{c}\text { Uniform nanoparticles in a } \\
\text { single-step reaction; need of a } \\
\text { low amount of reagents } \\
\text { required }\end{array}$ & $\begin{array}{c}\text { Long time required; need of a } \\
\text { high amount of template and } \\
\text { solvent }\end{array}$ \\
\hline Emulsion polymerization [73] & $\begin{array}{l}\text { Polymerization in } \\
\text { emulsions in the presence of a } \\
\text { surfactant }\end{array}$ & $\begin{array}{l}\text { High yield; suitability to } \\
\text { protein imprinting }\end{array}$ & $\begin{array}{l}\text { Required purification; } \\
\text { use of a stabilizer }\end{array}$ \\
\hline $\begin{array}{c}\text { Core-shell grafting }+ \\
\text { polymerization [114-121] }\end{array}$ & $\begin{array}{c}\text { Polymerization occurs around } \\
\text { preformed } \\
\text { nanoparticles }\end{array}$ & Control on MIPs size & $\begin{array}{l}\text { Not effective for bulky } \\
\text { templates }\end{array}$ \\
\hline $\begin{array}{l}\text { Solid-phase synthesis } \\
{[122,123]}\end{array}$ & $\begin{array}{l}\text { Polymerization follows the } \\
\text { immobilization of the } \\
\text { template molecule on glass } \\
\text { beads }\end{array}$ & $\begin{array}{l}\text { Very high affinity; } \\
\text { homogeneous } \\
\text { distribution of the recognition } \\
\text { sites; recycle of the template }\end{array}$ & $\begin{array}{l}\text { Low yield; not effective for } \\
\text { thermosensitive and bulky } \\
\text { templates }\end{array}$ \\
\hline $\begin{array}{l}\text { High dilution } \\
\text { polymerization }[124,125]\end{array}$ & $\begin{array}{l}\text { The monomer is dissolved in } \\
\text { a high amount of } \\
\text { solvent to avoid precipitation } \\
\text { during the process }\end{array}$ & MIPs size is equal to a few $\mathrm{nm}$ & High amount of solvent \\
\hline
\end{tabular}

Moreover, surface-imprinted materials have recognition sites on the polymeric surface [110] and exhibit an enhanced selectivity and sensitivity [126] improving recognition effectiveness. They are produced by localizing the template on the polymeric surface [127] and the most frequently employed techniques are the solid-phase approach and emulsion polymerization $[128,129]$.

A particular strategy, adopted when the template is a molecule difficult to obtain or to imprint due to the big size, is fragment imprinting, also called segment imprinting, which employs a portion of the target molecule as a pseudo-template to produce MIPs [130].

Dummy template imprinting is a method that uses substances similar to target molecules as templates for imprinting. This is useful when the templates are expensive or toxic molecules [131].

Like natural proteins after translation, MIPs can undergo post-imprinting chemical modifications [132], which consist of the addition of new functional groups, the transfor- 
mation of functional groups and the conjugation with molecules (Figure 9) [133]. This approach is very useful to enhance the specificity and the sensitivity of MIPs. For this method, it is necessary that the functional monomers used for the polymerization contain functional groups that can be chemically modified, such as amino or carboxyl groups, or reversible bonds including disulphide and imine bonds. After molecular imprinting, it is possible to modify monomer residues with hydrolysis and other reaction mechanisms. Post-imprinting modifications allow to remove functional moieties that are undesired for MIPs applications or to introduce desired groups, without losing the selectivity and the specificity of molecular recognition.

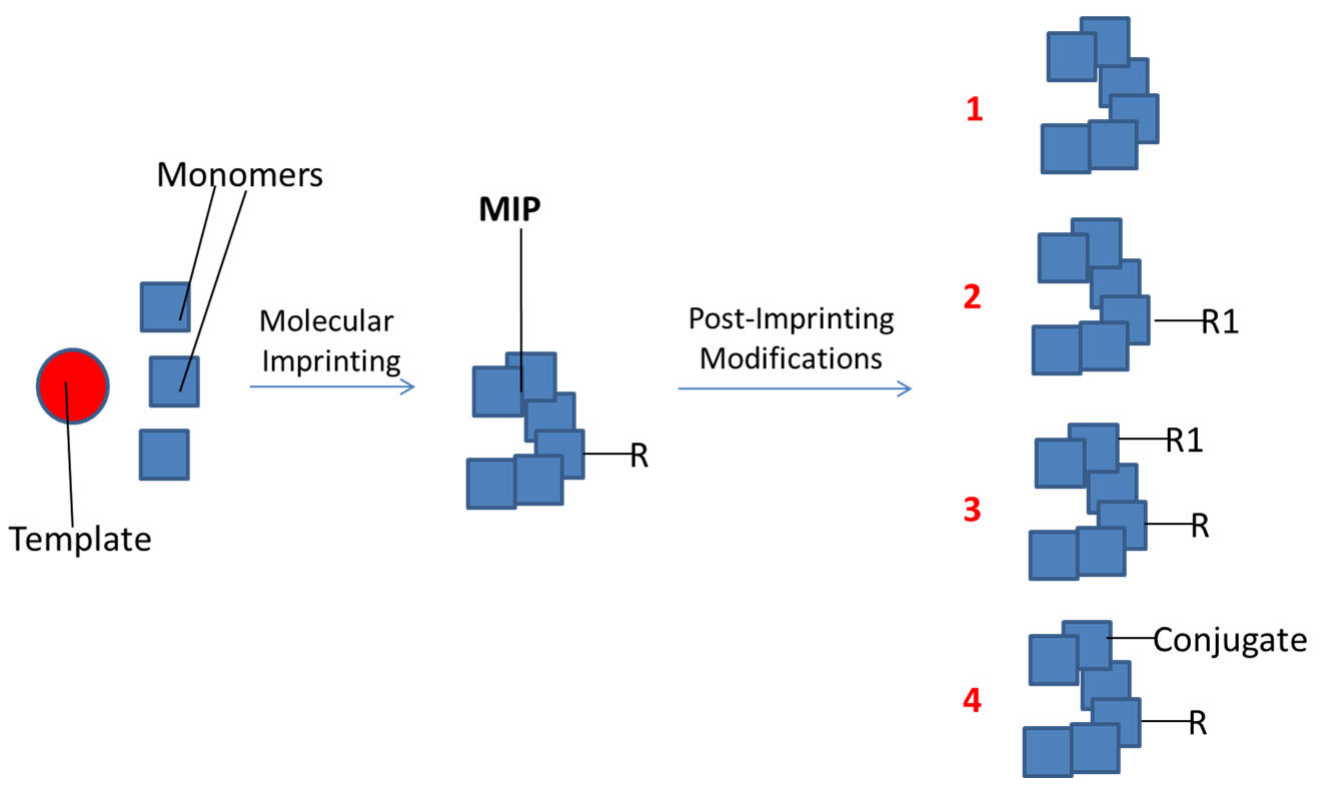

Figure 9. Post-imprinting modifications: (1) removal of a functional group; (2) transformation of a functional group; (3) addition of a new group; (4) conjugation with another molecule.

The site-specific introduction of fluorescent dyes is a very useful application of postimprinting modifications. For example, Saeki et al. [134] reported a MIP for the detection of prostate-specific antigen (PSA). In detail, after the molecular imprinting phase, two post-imprinting modifications were made to the polymer. First, PIR-C, which is a new PIM (post-imprinting modification) reagent, was introduced reacting with polymer thiol groups and obtaining molecularly imprinted nanocavities with orthogonal dual interaction sites, in particular, 3-fluorophenyl boronic acid for the binding of PSA sugar chains and carboxyphenyl groups for PSA proteins linkage, fundamental for the specificity and selectivity of the interaction MIP-target. Then, the fluorescent dye Alexa Fluor 647 was introduced with the second post-imprinting modification on PIR-C secondary amino groups.

Furthermore, in order to avoid one of the limits of molecular imprinting, that is to say, the heterogeneity of the recognition sites in terms of affinity, another post-imprinting modification has been introduced: the capping. A good solution is the block of the functional monomer residues in the cavities with low affinity, followed by specific post-imprinting modifications of the residues in the high-affinity cavities [132]. A representative example is the development of a fluorescent MIP for lysozyme recognition. After the preparation of the lysozyme-imprinted polymer, a diluted lysozyme solution was added to the MIP film to protect the functional monomer residues in the high-affinity binding cavities. After that, the capping treatment was applied to the residues in the binding cavities with low affinity: p-isothiocyanatophenyl $\alpha$-D-mannopyranoside reacted with the amino groups on the functional monomer moieties blocking them to the conjugation with the fluorescent molecule, which occurred instead in the high-affinity cavities. According to the experimental results, the capping significantly increased the MIPs selectivity [135]. 


\subsection{Applications of MIPs as Antibodies}

Molecular recognition is a fundamental MIPs property that, together with the fact that they are resistant in various chemical and physical conditions $(\mathrm{pH}$, temperature, organic solvents, pressure) [77], makes these synthetic macromolecules potentially suitable for many applications.

\subsubsection{Sensors, Bioassays and Diagnostic Applications}

Classical bioassays, such as ELISA, are widespread, even if they are expensive and consist of long procedures [136]. Until MIPs were prepared through bulk polymerization, they were made up of microparticles [121], so they could not be used in bioassays due to the difficulty in immobilizing MIPs in microplate wells. When the techniques for obtaining MIP nanoparticles, such as solid-phase synthesis, were devised, MIPs acting as plastic antibodies (synthetic polymer nanoparticles with antibody-like functions as potential alternatives to protein antibodies [104]) started to be studied for pseudo-ELISA assays. For example, very sensitive assays for the detection of the antibiotics vancomycin [137] and gentamycin [138], cocaine [139] and bisphenol A (BPA) [140], containing MIP nanoparticles physically immobilized on the microplate surface, have been developed reducing production time and costs, with better stability that consents a long shelf-life [103]. In detail, a horseradish peroxidase (HRP)-template conjugate was used and the sensitivity was much higher than in other ELISA tests [121].

All these studies demonstrated that MIP nanoparticles, obtained by solid-phase synthesis, can find application in the development of pseudo-ELISA assays for the detection of target molecules in real samples and characterized by high selectivity and sensitivity and other advantages including the impact on time and cost of production cycles compared to traditional ELISA.

Other examples of MIPs for assay applications are the production of a MIP through solgel polymerization on the surface of microplates using recombinant human erythropoietin$\alpha$ (rhEPO) as a template molecule [141], and the surfactant-mediated sol-gel polymerization in an aqueous environment designed in order to get MIPs for protein recognition [142]. Furthermore, new possibilities emerged using magnetic MIPs in microplates [143]. For example, magnetic nanoMIPs are employed in blood typing assays. MIPs were imprinted with blood type B trisaccharide [144] and the erythrocytes were removed from the solution by magnetic MIPs, causing decolourization. Antibodies used in biological sensors due to their high affinity and specificity, indeed, are vulnerable to denaturation when changes in temperature, $\mathrm{pH}$ and/or salinity occur. In these conditions, antibody-based blood typing tests might generate incorrect results. Therefore, the development of MIPs-based antibodies able to combine the selective recognition abilities of biological antibodies with the higher stability and low-cost production of the artificial counterpart was attractive as alternative to be employed in blood typing systems.

The molecularly imprinted polymer nanoparticles assay (MINA) was used for the analysis of biotin [145] and it exploits the competition of fluorescent nanoMIPs binding towards the free analyte and the analyte immobilized on magnetic inserts. The developed MINA allows to avoid the interference of other compounds, such as mercaptoethanol and sugars, that are well-known to affect traditional avidin and streptavidin-based assays. MINA has also been applied to the detection of the insecticide methyl parathion (MP) [146], proteins [147], leukotrienes and insulin [148] in biological samples. In particular, the developed MINA test for the detection of methyl parathion exhibited a high specificity and a linearity in a wide concentration range similar to ELISA. In addition, the assay allowed MP detection at picomolar concentrations without any cross-reactivity against other compounds such as chlorpyriphos and fenthion. Regarding MINA for leukotrienes and insulin detection, the assay showed comparable performance to existing chromatographic techniques, such as LC-MS/MS, and immunoassays in clinically relevant concentrations and using artificial urine and blood plasma. Therefore, MINA represents a very effective and versatile technique, which allows the use of stable reagents and the production of low-cost 
assays free of animal products. Other advantages are the fact that it can be applicable to many targets of clinical or environmental interest and to many kinds of matrix. Moreover, MIPs stability makes not necessary particular storage conditions and no washing steps or addition of enzyme substrates are required compared to the standard ELISA.

Furthermore, MIPs-based sensors have been devised, such as quartz crystal microbalance (QCM) and surface plasmon resonance (SPR) sensors, which require a high density of recognition sites close to the transducer [103]. For this application, MIP nanofilm is obtained through electropolymerization [149] or surface grafting [150]. Examples are the imprinted SPR sensors for the recognition of Salmonella paratyphi in contaminated water and food supplies, which provided a biosensing system characterized by good sensitive and selective responses [151], and QCM-based sensors for the recognition of tobacco mosaic virus also in complex matrices such as tobacco plant sap [152] and human rhinovirus antibodies [153]. Standard methods for the detection of microbial contaminants and the screening of viral infections, indeed, take a lot of time and effort due to the need for several experimental steps including sample preparation, cultivation, biochemical identification and serological confirmation. Therefore, the development of alternative and suitable control strategies attracts significant interest.

One of the most recent examples of sensors is provided by Li et al. [154], who proposed an electropolymerization to obtain a system for the detection of deoxynivalenol (DON) by combining a highly-sensitive and selective sensor based on molecularly imprinted poly(L-arginine) with functionalized carbon nanotubes.

A MIP-based electrochemical sensor for the detection of SARS-CoV-2 nucleoprotein has recently been developed [155]. The sensor is formed of a thin film electrode interfaced with a MIP synthesized to recognize SARS-CoV-2 nucleoprotein (ncovNP) and it is connected with a portable potentiostat.

Moreover, a sandwich assay electrochemical biosensor was developed by You et al. [156] for the detection of amyloid- $\beta$ oligomer $(\mathrm{A} ß \mathrm{O})$, known as the biomarker of Alzheimer's disease, through the formation of a sandwich composed of an aptamer and a MIP. In detail, core-shell nanoparticles, made up of silver and silica, presented the aptamer on their own surface. The described biosensor displayed high specificity, sensitivity, reproducibility and stability demonstrating the ability to detect $\mathrm{A} ß \mathrm{O}$ in human serum. Therefore, it could represent an innovative approach for the early diagnosis of Alzheimer's disease characterized by several advantages including its low cost and the simplicity of the sample pre-treatment compared to natural antibodies employed in $\mathrm{A} \beta \mathrm{O}$ detection.

The development of an electrochemical sensor with a MIP film for the detection of an antigen expressed in colorectal cancer (CEA, carcinoembryonic antigen), has been reported by Carneiro et al. [157]. The MIP layer was made up of polypyrrol, assembled in situ and combined with a poly(3,4-ethylenedioxythiophene) layer. The obtained sensor showed linear responses over a wide concentration range and high selectivity and reproducibility, thus, representing a very promising instrument to be used in CEA determination.

Finally, a MIP obtained via the polymerization of a thiourea-based fluorescent functional monomer was obtained for the detection of non-steroidal anti-inflammatory drugs (NSAIDs), such as indomethacin and tolmetin [158]. Micromolar binding affinities were obtained in aqueous solution with performances similar to the ones observed for polyclonal antibodies.

Table 2 reports a summary of MIP-based bioassays or sensors. 
Table 2. Some examples of MIP-based bioassays and sensors.

\begin{tabular}{|c|c|c|c|c|}
\hline Bioassay or Sensor & Synthesis Technique & Targets & Key Findings & References \\
\hline Pseudo-ELISA & Solid-phase approach & $\begin{array}{l}\text { BPA, vancomycin, } \\
\text { gentamycin, cocaine }\end{array}$ & $\begin{array}{l}\text { Sensitivity better than previously } \\
\text { described antibodies-based ELISA; } \\
\text { low cross-reactivity }\end{array}$ & [137-140] \\
\hline Blood typing assays & Solid-phase approach & Blood antigens & $\begin{array}{l}\text { First example of preparation of } \\
\text { MIPs for the selective recognition } \\
\text { of a } \\
\text { trisaccharide and potential } \\
\text { application for diagnostic } \\
\text { purposes; an effective } \\
\text { alternative based on MIP materials } \\
\text { to the use of conventional } \\
\text { antibodies in the blood typing } \\
\text { assays }\end{array}$ & [144] \\
\hline
\end{tabular}

\begin{tabular}{|c|c|c|}
\hline $\begin{array}{l}\text { Molecularly } \\
\text { imprinted polymer } \\
\text { nanoparticles } \\
\text { assay } \\
\text { (MINA) }\end{array}$ & Solid-phase approach & $\begin{array}{c}\text { Biotin, methyl } \\
\text { parathion, } \\
\text { proteins, } \\
\text { leukotrienes, insulin }\end{array}$ \\
\hline
\end{tabular}

High stability during storage also without refrigeration; no susceptibility to other molecules able to affect avidin and streptavidin-based assays; no cross-reactivity

Selective and sensitive MIP-based SPR biosensors for monitoring of microbial contaminants; monitoring of plant

viruses directly in the plant sap within minutes; plastic copies of QCM sensors surface grafting paratyphi, tobacco mosaic virus, human rhinovirus antibodies antibodies synthesized by imprinting

procedures lead to very promising QCM systems for virus sensing

\begin{tabular}{lcccc}
\hline $\begin{array}{c}\text { Electrochemical } \\
\text { biosensors }\end{array}$ & Electropolymerization & $\begin{array}{c}\text { Amyloid- } \beta \text { oligomer, } \\
\text { colorectal } \\
\text { cancer marker }\end{array}$ & $\begin{array}{c}\text { High specificity, sensitivity, } \\
\text { reproducibility and stability }\end{array} \quad$ [156,157] \\
\hline Fluorescent sensing & $\begin{array}{c}\text { Free-radical } \\
\text { Polymerization }\end{array}$ & NSAIDs & $\begin{array}{c}\text { Performances similar to the ones } \\
\text { observed for polyclonal antibodies }\end{array} \quad$ [158] \\
\hline
\end{tabular}

Desired characteristics for probes for bioimaging applications include the lack of toxic effects, biocompatibility and biodegradability or, if not possible, the possibility of rapid excretion [159]. MIP nanoparticles can be cleared through the kidneys if their hydrodynamic diameter is smaller than $8 \mathrm{~nm}$, or through the liver. Other important characteristics for imaging are specificity, selectivity, affinity, size (preferably less than $100 \mathrm{~nm}$ ), charge (cations have better reactivity with cells, whereas anions are less toxic) [111]. Parameters important to consider, specific for in vivo imaging, are biocompatibility, fluorescence (fluorophores need to emit in the near-infrared range to penetrate in deep tissues) and opsonisation, which needs to be avoided because immunoglobulins, in the blood stream, recognize nanoparticles as stranger elements and the immune system promotes their elimination. This last problem was solved by resorting to the coating of the MIP nanoparticles with a hydrophilic polymer layer of PEG [160] or albumin [161].

Bioimaging of glycans is fundamental to recognizing many pathological states such as cancer [111]. MIPs are important alternatives to antibodies and lectins, which form only weak interactions with polysaccharides [162]. NanoMIPs for bioimaging applications can easily be coupled with quantum dots [163] or fluorescent dyes [164] via surface functionalization. 
A specific and selective MIP for the imaging of hyaluronic acid, a tumour biomarker, on epidermal keratinocytes was synthesized by precipitation polymerization [165]. For this purpose, D-glucuronic acid, which is a constituent of hyaluronic acid, was used as a template, (N-acrylamido)-benzamidine (AAB) and methacrylamide (MAM) were used as functional monomers and a polymerizable rhodamine derivative was employed as a fluorescent dye. This research study confirmed the applicability of fluorescently labelled MIP nanoparticles as artificial antibodies able to localize specific molecular targets, such as glycosylation sites on proteins, for cell and tissue imaging.

An example of MIPs-quantum dots for bioimaging is provided by Panagiotopoulou et al. [166], who devised a system based on quantum dots and core-shell MIPs made up of (4-acrylamidophenyl)(amino)methaniminium acetate and methacrylamide for the detection of cancer biomarkers D-glucuronic acid and $\mathrm{N}$-acetylneuraminic acid, a component of sialic acid, on human keratinocytes at the same time. MIPs synthesized through photopolymerization, templated with D-glucuronic acid and coating carbon dots (CDs) [167] for the detection of hyaluronic acid in cancer and normal tissue are also present in literature. A poly(N-isopropylacrylamide)-based MIP, copolymerized with (4-acrylamidophenyl) (amino)methaniminium acetate and rhodamine B as functional and fluorescent monomers, respectively, was obtained by solid-phase synthesis [168] for the same purpose. Using this approach allows the synthesis of MIPs with the size of a few $\mathrm{nm}$ and homogeneous recognition sites. The difference is that an azide derivative of D-glucuronic acid was used as a template and immobilized on propargylated functionalized glass beads.

Monosaccharides, such as mannose and fucose, are other cancer biomarkers, thus, many imaging techniques involving their recognition have recently been developed. For example, fluorescein isothiocyanate-doped silica nanoparticles, alternatively imprinted with fucose, mannose and sialic acid [111,125], were produced for specific and selective bioimaging and tested on human hepatoma carcinoma cells (HepG-2), normal hepatic cells (L-02), mammary cancer cells (MCF-7) and normal mammary epithelial cells (MCF-10A). Similar results were obtained with nanoMIPs associated with three quantum dots (emitting in the wavelengths corresponding to green, yellow and red) for multiplexed bioimaging [169]. Moreover, solid-phase is the best synthetic approach for bioimaging applications, because the fact that nanoMIPs are smaller allows the recognition of intracellular molecules, with results similar to the staining obtained with natural antibodies [111].

The latest studies described highlighted the high versatility and the potential for bioimaging of MIPs, which can be designed and prepared against a wide range of targets, from sugars and single amino acids to entire proteins. In addition, the combination of MIP materials with therapeutic agents and/or fluorescent/magnetic probes allows to obtain multimodal systems able to act as theranostic devices.

\subsubsection{Double-Imprinted Polymers as Targeted Drug Delivery Systems (TDDSs)}

MIPs have been reported to be used for the controlled delivery of nutraceuticals $[170,171]$ and therapeutic agents against cancer [172,173], when these compounds are employed as templates in the pre-polymerization stage, due to their high loading capacity and the good control exerted in the release process. In addition, MIP materials can also act as targeted drug delivery systems (TDDSs) able to recognize and bind specific cell markers and, thus, release the therapeutic agent to the target site avoiding side effects and improving patient compliance. In this case, the cell marker was used as a template while the drug can be loaded or conjugated to the polymeric material.

Another very interesting approach to prepare MIP-based TDDSs is represented by double imprinting in which both the drug and the targeting agent are used simultaneously as templates. Double-imprinted polymers, indeed, are able to protect the therapeutic agent, prolong its release profile and, at the same time, to localize the drug delivery to the desired site improving the therapeutic profile and, thus, the therapeutic effects [174].

Double-imprinted MIP-coated mesoporous silica nanospheres were prepared using a conformational epitope of HER2 (Human epidermal growth factor) and doxorubicin as 
templates and dopamine as monomer. In detail, the MIP material was synthesized on the surface of silica nanoparticles according to the non-covalent imprinting approach and in vivo studies were carried out on human ovarian tumour-bearing mice showing that the drug concentration in the tumour was higher in the animal group treated with the developed doxorubicin-loaded delivery system [175].

In another study, doxorubicin was used as a template, together with a linear epitope of the epidermal growth factor receptor (EGFR) that is over-expressed in several tumours, to prepare a double-imprinted nanoMIP by solid-phase synthesis. The developed doxorubicinloaded anti-EGFR nanoMIP was tested on different cancer cell lines and cytotoxicity and apoptosis were observed only in cells that over-expressed EGFR [176].

\subsubsection{Therapeutic Applications}

The first therapeutic MIP, developed in 2010, was able to bind and neutralize the bee toxin melittin in mice blood reducing mice mortality [177]. The field in which MIPs have been more employed is cancer pharmacology and an important requirement for MIPs is a long retention time in the tumour tissue to deliver the drug [178].

A strategy for this purpose is the targeting of cadherins [111], proteins that promote cell-cell adhesion, whose uncontrolled expression favours cancer proliferation [179]. For this kind of application, an oligopeptide, a fragment of cadherin structure, was used as a template. The thermo-responsive MIPs were synthesized by solid-phase polymerization of $\mathrm{N}$ isopropylacrilamide (NIPAM), N-tert-butylacrylamide (TBAM), N-phenylacrylamide (PAA) and 4-acrylamidophenyl (amino)-methaniminium acetate in the presence of the crosslinking agent with the oligopeptide immobilized on azide-functionalized glass beads [180]. The results of the study showed that MIPs were selective and significantly reduced the proliferation of tumour cells, more than monoclonal antibodies.

Another option for cancer therapy is the inhibition of the HER2 pathway [111]. In detail, HER2 is overexpressed in breast cancer [181] and exerts its action by dimerization with other proteins, like HER3. The inhibition of this interaction was previously achieved by monoclonal antibodies, but MIPs obtained via boronate affinity-oriented surface imprinting polymerization and conjugated with silica nanoparticles containing fluorescein isothiocyanate revealed themselves more effective in decreasing the cancer tissue in female mice [182].

Furthermore, MIPs are potentially applicable for the treatment of infectious pathologies because they can recognize and block components of etiological agents, such as bacteria, viruses, fungi and protista, involved in infection mechanisms. For example, Parisi et al. [183] used non-covalent imprinting to prepare a MIP able to recognize and bind the receptor-binding domain of the spike protein of SARS-CoV-2 (COVID-19 etiological agent), a surface glycoprotein involved in the recognition and the attachment to host cells [184]. The obtained imprinted nanoparticles were able to significantly inhibit virus replication in Vero cells culture.

\subsubsection{Theranostic Applications}

A growing number of theranostic applications of MIPs are emerging, exploiting the recognition properties of this kind of polymers for the simultaneous imaging and delivery of active molecules for the treatment and the ablation of cancer tissue by heat or reactive oxygen radicals [111]. In particular, nanoparticles seem to be the better mean for drug delivery in the whole organism [185,186]. Interesting characteristics of MIPs are the possibility of drug protection, reduced toxicity (especially for highly toxic anticancer drugs), controlled release and widespread distribution. Lately, MIPs have been used to target many membrane receptors, which are cancer biomarkers [118,187-190].

For example, MIPs selective for the epidermal growth factor receptor (EGFR) were synthesized by acrylamide reverse microemulsion polymerization in the presence of the crosslinking agent BIS and in association with red-emitting carbon dots [118]. 
In another study, a fluorescent MIP was designed for the delivery of doxorubicin. In detail, the MIP was made up of zinc acrylate, which interacted with the template through metal chelation, and acrylamide, which exploited hydrogen bonds and was synthesized via free radical polymerization and conjugated to fluorescent silicon nanoparticles [187]. In this case, the in vivo target was HER2, a glycoprotein overexpressed in breast tumour cells. In addition, the acidic environment in tumour tissues was able to break hydrogen bonds, thus releasing the drug specifically there, and the fluorescence allowed real-time monitoring of both MIPs and doxorubicin.

MIPs composed of zinc acrylate, vinylphenylboronic acid and ethylene glycol dimethacrylate for the targeting of cancer cells in which Fn14 (fibroblast growth factor-inducible 14) is overexpressed, such as pancreas, brain and breast tumours and the delivery of the anticancer drug bleomycin were developed and tested in mice. The templates were the drug and a glycosylated epitope of Fn14, while silanized silicon nanoparticles with photoluminescence properties were used as the fluorescence source [188]. Bleomycin is released when the nanoparticles reach the cancer tissue with low $\mathrm{pH}$, which leads to the breakage of the bond between vinylphenylboronic acid and the therapeutic agent.

The folate receptor, overexpressed in various cancer cells, is another target of theranostic MIPs. In particular, MIPs, associated with fluorescein isothiocyanate linked to the nanoparticles and conjugated with poly(ethylene glycol)-folate, were obtained for precipitation polymerization in water using $\mathrm{N}$-acryloyl-phenylalanine and $\mathrm{N}$-acryloyl-lysine as functional monomers in the presence of the crosslinking agent $\mathrm{N}, \mathrm{N}^{\prime}$-bis(acryloyl)cystamine [190]. This last forms disulphide bonds that are reduced by the big amount of glutathione in tumour cells causing the release of the anticancer drug vinblastine. The developed MIPs revealed themselves effective in xenograft mice injected with human cervical cancer cells.

Opsonisation can be circumvented by coating the MIP surface with polymers like polyethylene glycol, which prevent opsonins to bind to MIPs, avoiding their fast clearance [191]. Another strategy to overcome opsonisation is MIP synthesis using plasmatic albumin as a template, so that a layer made up of albumin proteins, present in the blood, is formed around the MIP. In this context, a theranostic MIP was obtained by precipitation polymerization of pyrrolidyl acrylate, NIPAM, 2-methacryloyloxyethyl phosphorylcholine, BIS and fluorescein acrylamide [192]. The prepared fluorescein-conjugated MIP was able to bind albumin, forming an albumin-rich protein corona, and to be passively accumulated in tumour tissue suggesting that this approach could be effective in the development of theranostic nanosystems for cancer therapy.

Photothermal therapy is used, coupled to imaging, to lead tumour cells to death causing localized hyperthermia [193] and, in this case, MIPs are very good substitutes of antibodies. For this purpose, plasmonic nanostructures have been exploited [194]. A system composed of gold nanorods, coupled with sialic acid-imprinted silica, was produced by a boronate affinity-oriented surface imprinting approach [119]. The formulation, containing also a fluorescent dye, is bound to the template resulting in the selective ablation of cancer cells overexpressing sialic acid.

Another therapeutic technique, photodynamic therapy, based on the formation of a high amount of reactive oxygen species following light exposure on the target tissues, was associated with imaging. For the targeting of p32, MIPs able to recognize a conformational epitope of the extracellular N-terminal $\alpha$-helix of the protein as template [195] were obtained through inverse microemulsion polymerization of acrylamide and BIS. The synthesized MIPs, incorporating the dye IR-783 and loading the photosensitizer methylene blue, were able to selectively recognize and stain p32-positive tumour cells, applying on them photodynamic therapy with no toxicity in the other tissues.

For the targeting of folate receptor- $\alpha(\mathrm{FR} \alpha)$, MIPs, incorporating the dye IR-783 and loading the photosensitizer methylene blue, were synthesized through precipitation polymerization of acrylamide, 2-(trifluoromethyl)acrylic acid and BIS [196]. The template was an $\operatorname{FR} \alpha \mathrm{N}$-terminal peptide forced to be organized in an $\alpha$-helix structure. This formulation 
revealed itself able to localize the staining and the photodynamic effect on tumour cells overexpressing folate receptors.

With a similar strategy, Fn14 was targeted [197]. MIPs made up of acrylamide, BIS, TBAM and APMA, incorporating the dye IR-783 and loading the photosensitizer hypocrellin B, were synthesized using a transmembrane helical portion of Fn14 as a template. The obtained nanoparticles showed a good in vivo antitumor activity in mice upon laser activation and no cytotoxicity in sane tissues.

A MIP-based theranostic system, delivering the anticancer drug Sunitinib and incorporating the fluorescent marker Rhodamine $6 \mathrm{G}$, was recently devised. The synthetic strategy consisted of the precipitation polymerization of methacrylic acid and ethylene glycol dimethacrylate in the presence of the therapeutic agent, followed by the functionalization of the obtained MIPs with the dye through radical grafting [198].

\subsection{Comparison between MIPs, Antibodies and Aptamers}

Monoclonal antibodies and MIPs, due to their ability of molecular recognition, may have similar applications, with comparable affinity. Antibodies, in particular monoclonal antibodies, have poor chemical stability, reducing the shelf life of antibodies-based products and requiring a constant cold chain supply [103]. Instead, MIPs are stable in several environments, allowing the reuse of them for successive applications. In detail, MIPs are resistant to the variation of $\mathrm{pH}$, temperature and pressure and to the exposure to organic solvents [77].

Furthermore, as previously described, monoclonal antibodies production involves animals, with all the disadvantages that this determines, such as the unseemly production cost and time (months), as well as the need for specialized personnel [103]. One of MIPs advantages toward antibodies lies in the low cost for both the production process and the research and development phase for new formulations, with shorter production time (few weeks) [121]. Molecular imprinting technology is more versatile because of the possibility to choose among thousands of monomers, and MIPs are able to recognize a wider spectrum of molecules than monoclonal antibodies can. MIPs avoid also the typical problem of antibodies of the batch-to-batch variability and they have the useful possibility to be conjugated easily to other molecules.

Although MIPs present so many potential advantages towards the antibodies, many questions continue to be on these molecules, above all the lack of studies about their toxicity, immunogenicity and clearance and the absence of massive use of MIPs in clinical and research practice [103].

Moreover, from the comparison between MIPs and aptamers, it emerges that they have many common features: high affinity for targets, high thermal stability, production mode, a wide range of target molecules, the possibility of functionalisation, low batch-to-batch variability [121]. The main differences lie in the lower stability to $\mathrm{pH}$ and organic solvents of aptamers, the higher cost and time production and the limited possibility to choose monomers (four nitrogen bases).

Table 3 points out the main differences among antibodies, aptamers and MIPs.

Table 3. Main differences among antibodies, MIPs and aptamers.

\begin{tabular}{cccc}
\hline Characteristic & Antibodies & MIPs & Aptamers \\
\hline Thermal stability & Low & High & High \\
\hline pH stability & Low & High & Low \\
\hline Organic solvent stability & Low & High & Low \\
\hline Immunogenicity & High & Low & Medium \\
\hline Production cost & High & & L
\end{tabular}


Table 3. Cont.

\begin{tabular}{cccc}
\hline Characteristic & Antibodies & MIPs & Aptamers \\
\hline Production time & $>6$ months & Few weeks & Few months \\
\hline Production method & Animal immunization & Chemical synthesis & Chemical synthesis \\
\hline Batch-to-batch variability & High & Low & Low \\
\hline Amount of usable monomers & 20 (amino acids) & Thousands & (nitrogen bases) \\
\hline Amount of target molecules & Medium & High & High \\
\hline Possibility of functionalization & Low & High & Medium
\end{tabular}

\section{Conclusions}

This review focused on molecules with the capability to recognize specific targets. Antibodies naturally have this property and they have found a lot of applications in many fields: drug delivery, immunoassays and biosensors for diagnostics, immunotherapy, theranostic, biological and pharmacological research. Some limits of this kind of molecules, like low stability, high cost and immunogenicity, made necessary the research of other solutions, like aptamers and, above all, molecularly imprinted polymers. These last ones, although nowadays have not had great commercial success, showed many potential advantages toward their biological counterparts, such as low cost, versatility and stability.

For all these properties, it is worth investing further resources in MIPs research, in particular, to translate the existing knowledge of practical applications and evaluate immunogenicity, toxicity and clearance, which could be a limit for their usage.

Author Contributions: Conceptualization, O.I.P., F.F. and F.P. (Francesco Puoci); writing-original draft preparation, F.F., M.D. and F.P. (Francesco Patitucci); writing-review and editing, O.I.P., S.P., F.A. and F.P. (Francesco Puoci); supervision, O.I.P. and F.P. (Francesco Puoci); project administration, F.P. (Francesco Puoci). All authors have read and agreed to the published version of the manuscript.

Funding: This work was funded by PON “Ricerca e Innovazione" 2014-2020, Asse IV “Istruzione e ricerca per il recupero", Azione IV.4- “Dottorati e contratti di ricerca su tematiche dell'innovazione".

Conflicts of Interest: The authors declare no conflict of interest.

\section{References}

1. Bordon, Y. The many sides of Paul Ehrlich. Nat. Immunol. 2016, 17, S6. [CrossRef]

2. Forthal, D.N. Functions of antibodies. Microbiol. Spectr. 2014, 2, 1-17. [CrossRef]

3. Borghesi, L.; Milcarek, C. From B cell to plasma cell. Immunol. Res. 2006, 36, 27-32. [CrossRef]

4. Liu, H.; May, K. Disulfide bond structures of IgG molecules: Structural variations, chemical modifications and possible impacts to stability and biological function. MAbs 2012, 4, 17-23. [CrossRef]

5. Schroeder Jr, H.W.; Cavacini, L. Structure and function of immunoglobulins. J. Allergy Clin. Immunol. 2010, 125, S41-S52. [CrossRef]

6. Woof, J.M.; Burton, D.R. Human antibody-Fc receptor interactions illuminated by crystal structures. Nat. Rev. Immunol. 2004, 4, 89-99. [CrossRef]

7. Spiers, J. Goldberg's theory of antigen-antibody reactions in vitro. Immunology 1958, 1, 89.

8. Sela-Culang, I.; Kunik, V.; Ofran, Y. The structural basis of antibody-antigen recognition. Front. Immunol. 2013, 4, 302. [CrossRef]

9. Barclay, A.N. Membrane proteins with immunoglobulin-like domains-A master superfamily of interaction molecules. Semin. Immunol. 2003, 15, 215-223. [CrossRef]

10. Lisova, O.; Belkadi, L.; Bedouelle, H. Direct and indirect interactions in the recognition between a cross-neutralizing antibody and the four serotypes of dengue virus. J. Mol. Recognit. 2014, 27, 205-214. [CrossRef]

11. Gao, Y.; Huang, X.; Zhu, Y.; Lv, Z. A brief review of monoclonal antibody technology and its representative applications in immunoassays. J. Immunoass. Immunochem. 2018, 39, 351-364. [CrossRef]

12. Khan, F.H. Antibodies and their applications. In Animal Biotechnology; Elsevier: Amsterdam, The Netherlands, 2020 ; pp. 503-522.

13. Tillib, S. Prospective applications of single-domain antibodies in biomedicine. Mol. Biol. 2020, 54, 317-326. [CrossRef]

14. Goldsmith, S.J. Radioimmunoassay: Review of basic principles. Semin. Nucl. Med. 1975, 5, 125-152. [CrossRef] 
15. Kricka, L.J. Chemiluminescent and bioluminescent techniques. Clin. Chem. 1991, 37, 1472-1481. [CrossRef]

16. Gosling, J.P. A decade of development in immunoassay methodology. Clin. Chem. 1990, 36, 1408-1427. [CrossRef]

17. De Gassart, A.; Géminard, C.; Février, B.; Raposo, G.; Vidal, M. Lipid raft-associated protein sorting in exosomes. Blood 2003, 102, 4336-4344. [CrossRef]

18. Lequin, R.M. Enzyme immunoassay (EIA)/enzyme-linked immunosorbent assay (ELISA). Clin. Chem. 2005, 51, 2415-2418. [CrossRef]

19. Herzenberg, L.A.; Parks, D.; Sahaf, B.; Perez, O.; Roederer, M.; Herzenberg, L.A. The history and future of the fluorescence activated cell sorter and flow cytometry: A view from Stanford. Clin. Chem. 2002, 48, 1819-1827. [CrossRef]

20. Karn-Orachai, K.; Sakamoto, K.; Laocharoensuk, R.; Bamrungsap, S.; Dharakul, T.; Miki, K. SERS-based immunoassay on 2D-arrays of Au@ Ag core-shell nanoparticles: Influence of the sizes of the SERS probe and sandwich immunocomplex on the sensitivity. RSC Adv. 2017, 7, 14099-14106. [CrossRef]

21. Annio, G.; Jennings, T.L.; Tagit, O.; Hildebrandt, N. Sensitivity enhancement of forster resonance energy transfer immunoassays by multiple antibody conjugation on quantum dots. Bioconjugate Chem. 2018, 29, 2082-2089. [CrossRef]

22. Alber, F.; Dokudovskaya, S.; Veenhoff, L.M.; Zhang, W.; Kipper, J.; Devos, D.; Suprapto, A.; Karni-Schmidt, O.; Williams, R.; Chait, B.T. Determining the architectures of macromolecular assemblies. Nature 2007, 450, 683-694. [CrossRef] [PubMed]

23. Koczula, K.M.; Gallotta, A. Lateral flow assays. Essays Biochem. 2016, 60, 111-120. [PubMed]

24. Tian, W.; Wang, L.; Lei, H.; Sun, Y.; Xiao, Z. Antibody production and application for immunoassay development of environmental hormones: A review. Chem. Biol. Technol. Agric. 2018, 5, 1-12. [CrossRef]

25. Khramtsov, P.; Kropaneva, M.; Bochkova, M.; Timganova, V.; Zamorina, S.; Rayev, M. Solid-phase nuclear magnetic resonance immunoassay for the prostate-specific antigen by using protein-coated magnetic nanoparticles. Microchim. Acta 2019, 186, 1-7. [CrossRef]

26. Kellogg, D.; Rybalkin, I.; Chen, S.; Mukhamedova, N.; Vlasik, T.; Siebert, P.; Chenchik, A. TaqStart Antibody: “hot start” PCR facilitated by a neutralizing monoclonal antibody directed against Taq DNA polymerase. Biotechniques 1994, 16, 1134-1137.

27. Mahendra, A.; Sharma, M.; Rao, D.N.; Peyron, I.; Planchais, C.; Dimitrov, J.D.; Kaveri, S.V.; Lacroix-Desmazes, S. Antibodymediated catalysis: Induction and therapeutic relevance. Autoimmun. Rev. 2013, 12, 648-652. [CrossRef]

28. Farahavar, G.; Abolmaali, S.S.; Gholijani, N.; Nejatollahi, F. Antibody-guided nanomedicines as novel breakthrough therapeutic, diagnostic and theranostic tools. Biomater. Sci. 2019, 7, 4000-4016. [CrossRef]

29. Ding, F.; Gao, Y.; He, X.; Zhang, Y. Theranostic Applications of Antibody-Based Systems in Human Diseases. J. Biomed. Nanotechnol. 2018, 14, 405-429. [CrossRef]

30. Gabizon, A.; Shmeeda, H.; Barenholz, Y. Pharmacokinetics of pegylated liposomal doxorubicin. Clin. Pharmacokinet. 2003, 42, 419-436. [CrossRef]

31. Eck, W.; Craig, G.; Sigdel, A.; Ritter, G.; Old, L.J.; Tang, L.; Brennan, M.F.; Allen, P.J.; Mason, M.D. PEGylated gold nanoparticles conjugated to monoclonal F19 antibodies as targeted labeling agents for human pancreatic carcinoma tissue. ACS Nano 2008, 2, 2263-2272. [CrossRef]

32. Liang, S.; Li, C.; Zhang, C.; Chen, Y.; Xu, L.; Bao, C.; Wang, X. CD44v6 monoclonal antibody-conjugated gold nanostars for targeted photoacoustic imaging and plasmonic photothermal therapy of gastric cancer stem-like cells. Theranostics $2015,5,970$. [CrossRef] [PubMed]

33. Day, E.S.; Bickford, L.R.; Slater, J.H.; Riggall, N.S.; Drezek, R.A.; West, J.L. Antibody-conjugated gold-gold sulfide nanoparticles as multifunctional agents for imaging and therapy of breast cancer. Int. J. Nanomed. 2010, 5, 445. [CrossRef] [PubMed]

34. Webb, J.A.; Ou, Y.-C.; Faley, S.; Paul, E.P.; Hittinger, J.P.; Cutright, C.C.; Lin, E.C.; Bellan, L.M.; Bardhan, R. Theranostic gold nanoantennas for simultaneous multiplexed Raman imaging of immunomarkers and photothermal therapy. ACS Omega 2017, 2 , 3583-3594. [CrossRef] [PubMed]

35. Lu, R.-M.; Hwang, Y.-C.; Liu, I.-J.; Lee, C.-C.; Tsai, H.-Z.; Li, H.-J.; Wu, H.-C. Development of therapeutic antibodies for the treatment of diseases. J. Biomed. Sci. 2020, 27, 1-30. [CrossRef] [PubMed]

36. Kaplon, H.; Reichert, J.M. Antibodies to watch in 2019. MAbs 2019, 11, 219-238. [CrossRef]

37. Saini, K.S.; Azim Jr, H.A.; Cocorocchio, E.; Vanazzi, A.; Saini, M.L.; Raviele, P.R.; Pruneri, G.; Peccatori, F.A. Rituximab in Hodgkin lymphoma: Is the target always a hit? Cancer Treat. Rev. 2011, 37, 385-390. [CrossRef]

38. Hill, P.; Cross, N.B.; Barnett, A.N.R.; Palmer, S.C.; Webster, A.C. Polyclonal and monoclonal antibodies for induction therapy in kidney transplant recipients. Cochrane Database Syst. Rev. 2017, 1. [CrossRef]

39. Castelli, M.S.; McGonigle, P.; Hornby, P.J. The pharmacology and therapeutic applications of monoclonal antibodies. Pharmacol. Res. Perspect. 2019, 7, e00535. [CrossRef]

40. Grilo, A.L.; Mantalaris, A. The increasingly human and profitable monoclonal antibody market. Trends Biotechnol. 2019, 37, 9-16. [CrossRef]

41. Donini, C.; D'Ambrosio, L.; Grignani, G.; Aglietta, M.; Sangiolo, D. Next generation immune-checkpoints for cancer therapy. J. Thorac. Dis. 2018, 10, S1581. [CrossRef]

42. Burmester, G.R.; Panaccione, R.; Gordon, K.B.; McIlraith, M.J.; Lacerda, A.P. Adalimumab: Long-term safety in 23458 patients from global clinical trials in rheumatoid arthritis, juvenile idiopathic arthritis, ankylosing spondylitis, psoriatic arthritis, psoriasis and Crohn's disease. Ann. Rheum. Dis. 2013, 72, 517-524. [CrossRef] [PubMed] 
43. Sator, P. Safety and tolerability of adalimumab for the treatment of psoriasis: A review summarizing 15 years of real-life experience. Ther. Adv. Chronic Dis. 2018, 9, 147-158. [CrossRef] [PubMed]

44. Kuemmerle-Deschner, J.B.; Wittkowski, H.; Tyrrell, P.N.; Koetter, I.; Lohse, P.; Ummenhofer, K.; Reess, F.; Hansmann, S.; Koitschev, A.; Deuter, C. Treatment of Muckle-Wells syndrome: Analysis of two IL-1-blocking regimens. Arthritis Res. Ther. 2013, 15, 1-8. [CrossRef] [PubMed]

45. Singh, T.; Bedi, P.; Bumrah, K.; Singh, J.; Rai, M.; Seelam, S. Updates in treatment of recurrent Clostridium difficile infection. J. Clin. Med. Res. 2019, 11, 465. [CrossRef]

46. Kummerfeldt, C.E. Raxibacumab: Potential role in the treatment of inhalational anthrax. Infect. Drug Resist. 2014, 7, 101. [CrossRef]

47. Sebastian Mestel, D.; Beyer, M.; Möbs, M.; Steinhoff, M.; Sterry, W.; Assaf, C. Zanolimumab, a human monoclonal antibody targeting CD4 in the treatment of mycosis fungoides and Sezary syndrome. Expert Opin. Biol. Ther. 2008, 8, 1929-1939. [CrossRef]

48. Edvinsson, L.; Haanes, K.A.; Warfvinge, K.; Krause, D.N. CGRP as the target of new migraine therapies-Successful translation from bench to clinic. Nat. Rev. Neurol. 2018, 14, 338-350. [CrossRef]

49. Faienza, M.F.; Chiarito, M.; D’amato, G.; Colaianni, G.; Colucci, S.; Grano, M.; Brunetti, G. Monoclonal antibodies for treating osteoporosis. Expert Opin. Biol. Ther. 2018, 18, 149-157. [CrossRef]

50. Alving, C.R.; Wassef, N.M.; Potter, M. Antibodies to cholesterol: Biological implications of antibodies to lipids. Immunol. Silicones 1996, 181-186.

51. Hartley, J. Antibody-Drug Conjugates Delivering DNA Cytotoxics. In Cancer Drug Des. Discov, 2nd Ed.; Neidle, S., Ed.; Elsevier: Amsterdam, Netherlands, 2014; pp. 479-490.

52. Yoo, J.; Park, C.; Yi, G.; Lee, D.; Koo, H. Active targeting strategies using biological ligands for nanoparticle drug delivery systems Cancers 2019, 11, 640. [CrossRef]

53. Cheng, J.; Teply, B.A.; Sherifi, I.; Sung, J.; Luther, G.; Gu, F.X.; Levy-Nissenbaum, E.; Radovic-Moreno, A.F.; Langer, R.; Farokhzad, O.C. Formulation of functionalized PLGA-PEG nanoparticles for in vivo targeted drug delivery. Biomaterials 2007, 28, 869-876. [CrossRef] [PubMed]

54. Arslan, F.B.; Atar, K.O.; Calis, S. Antibody-mediated drug delivery. Int. J. Pharm. 2021, 596, 120268. [CrossRef] [PubMed]

55. Fiandra, L.; Mazzucchelli, S.; De Palma, C.; Colombo, M.; Allevi, R.; Sommaruga, S.; Clementi, E.; Bellini, M.; Prosperi, D.; Corsi, F. Assessing the in vivo targeting efficiency of multifunctional nanoconstructs bearing antibody-derived ligands. Acs Nano 2013, 7, 6092-6102. [CrossRef] [PubMed]

56. Milstein, C. The hybridoma revolution: An offshoot of basic research. Bioessays 1999, 21, 966-973. [CrossRef]

57. Morrison, S.L.; Johnson, M.J.; Herzenberg, L.A.; Oi, V.T. Chimeric human antibody molecules: Mouse antigen-binding domains with human constant region domains. Proc. Natl. Acad. Sci. USA 1984, 81, 6851-6855. [CrossRef]

58. Jones, P.T.; Dear, P.H.; Foote, J.; Neuberger, M.S.; Winter, G. Replacing the complementarity-determining regions in a human antibody with those from a mouse. Nature 1986, 321, 522-525. [CrossRef]

59. Alfaleh, M.A.; Alsaab, H.O.; Mahmoud, A.B.; Alkayyal, A.A.; Jones, M.L.; Mahler, S.M.; Hashem, A.M. Phage display derived monoclonal antibodies: From bench to bedside. Front. Immunol. 2020, 11, 1986. [CrossRef]

60. Lipman, N.S.; Jackson, L.R.; Trudel, L.J.; Weis-Garcia, F. Monoclonal versus polyclonal antibodies: Distinguishing characteristics, applications, and information resources. ILAR J. 2005, 46, 258-268. [CrossRef]

61. Laflamme, C.; McKeever, P.M.; Kumar, R.; Schwartz, J.; Kolahdouzan, M.; Chen, C.X.; You, Z.; Benaliouad, F.; Gileadi, O.; McBride, H.M. Implementation of an antibody characterization procedure and application to the major ALS/FTD disease gene C9ORF72 Elife 2019, 8, e48363. [CrossRef]

62. Bauer, M.; Strom, M.; Hammond, D.S.; Shigdar, S. Anything you can do, I can do better: Can Aptamers replace antibodies in clinical diagnostic applications? Molecules 2019, 24, 4377. [CrossRef]

63. Spicer, S.S.; Spivey, M.; Ito, M.; Schulte, B.A. Some ascites monoclonal antibody preparations contain contaminants that bind to selected Golgi zones or mast cells. J. Histochem. Cytochem. 1994, 42, 213-221. [CrossRef] [PubMed]

64. Bradbury, A.; Plückthun, A. Reproducibility: Standardize antibodies used in research. Nat. News 2015, 518, 27. [CrossRef] [PubMed]

65. Colas, P.; Cohen, B.; Jessen, T.; Grishina, I.; McCoy, J.; Brent, R. Genetic selection of peptide aptamers that recognize and inhibit cyclin-dependent kinase 2. Nature 1996, 380, 548-550. [CrossRef] [PubMed]

66. Mallikaratchy, P. Evolution of complex target SELEX to identify aptamers against mammalian cell-surface antigens. Molecules 2017, 22, 215. [CrossRef] [PubMed]

67. Jayasena, S.D. Aptamers: An emerging class of molecules that rival antibodies in diagnostics. Clin. Chem. 1999, 45, 1628-1650. [CrossRef] [PubMed]

68. Wei, H.; Li, B.; Li, J.; Wang, E.; Dong, S. Simple and sensitive aptamer-based colorimetric sensing of protein using unmodified gold nanoparticle probes. Chem. Commun. 2007, 3735-3737. [CrossRef]

69. Cheng, H.; Qiu, X.; Zhao, X.; Meng, W.; Huo, D.; Wei, H. Functional nucleic acid probe for parallel monitoring K+ and protoporphyrin IX in living organisms. Anal. Chem. 2016, 88, 2937-2943. [CrossRef]

70. Kumar Kulabhusan, P.; Hussain, B.; Yüce, M. Current perspectives on aptamers as diagnostic tools and therapeutic agents Pharmaceutics 2020, 12, 646

71. Zhang, Y.; Lai, B.S.; Juhas, M. Recent advances in aptamer discovery and applications. Molecules 2019, 24, 941. [CrossRef] 
72. Frejd, F.Y.; Kim, K.-T. Affibody molecules as engineered protein drugs. Exp. Mol. Med. 2017, 49, e306. [CrossRef]

73. Haupt, K.; Medina Rangel, P.X.; Bui, B.T.S. Molecularly imprinted polymers: Antibody mimics for bioimaging and therapy. Chem. Rev. 2020, 120, 9554-9582. [CrossRef] [PubMed]

74. Bellis, S.L. Advantages of RGD peptides for directing cell association with biomaterials. Biomaterials 2011, 32, 4205-4210. [CrossRef] [PubMed]

75. Wang, F.; Li, Y.; Shen, Y.; Wang, A.; Wang, S.; Xie, T. The functions and applications of RGD in tumor therapy and tissue engineering. Int. J. Mol. Sci. 2013, 14, 13447-13462. [CrossRef] [PubMed]

76. Fernández, M.; Javaid, F.; Chudasama, V. Advances in targeting the folate receptor in the treatment/imaging of cancers. Chem. Sci. 2018, 9, 790-810. [CrossRef]

77. Parisi, O.I.; Puoci, F. Stimuli-responsive Molecularly Imprinted Polymers. In Chemoresponsive Materials; Royal Society of Chemistry: London, UK, 2015; pp. 364-383.

78. Polyakov, M. Adsorption properties and structure of silica gel. Zhur Fiz Khim 1931, 2, 799-805.

79. Dickey, F.H. The preparation of specific adsorbents. Proc. Natl. Acad. Sci. USA 1949, 35, 227. [CrossRef]

80. Wulff, G. The use of polymers with enzyme-analogous structures for the resolution of racemates. Angrew. Chem. Internat. Edit. $1972,11,341$

81. Arshady, R.; Mosbach, K. Synthesis of substrate-selective polymers by host-guest polymerization. Die Makromol. Chem. Macromol. Chem. Phys. 1981, 182, 687-692. [CrossRef]

82. Yan, H.; Row, K.H. Characteristic and synthetic approach of molecularly imprinted polymer. Int. J. Mol. Sci. 2006, 7, 155-178. [CrossRef]

83. Wulff, G.; Sarhan, A.; Zabrocki, K. Enzyme-analogue built polymers and their use for the resolution of racemates. Tetrahedron Lett. 1973, 14, 4329-4332.

84. Wulff, G.; Vesper, W.; Grobe-Einsler, R.; Sarhan, A. Enzyme-analogue built polymers, 4. On the synthesis of polymers containing chiral cavities and their use for the resolution of racemates. Die Makromol. Chem. Macromol. Chem. Phys. 1977, 178, $2799-2816$. [CrossRef]

85. Chen, L.; Xu, S.; Li, J. Recent advances in molecular imprinting technology: Current status, challenges and highlighted applications. Chem. Soc. Rev. 2011, 40, 2922-2942. [CrossRef] [PubMed]

86. Vlatakis, G.; Andersson, L.I.; Müller, R.; Mosbach, K. Drug assay using antibody mimics made by molecular imprinting. Nature 1993, 361, 645-647. [CrossRef] [PubMed]

87. Andersson, L.; Sellergren, B.; Mosbach, K. Imprinting of amino acid derivatives in macroporous polymers. Tetrahedron Lett. 1984, 25, 5211-5214. [CrossRef]

88. Zhou, J.; He, X.; Li, Y. An acrylamide-based molecularly imprinted polymer for the efficient recognition of optical amino acid hydantoins. Anal. Commun. 1999, 36, 243-246. [CrossRef]

89. Takagishi, T.; Hayashi, A.; Kuroki, N. Cross-linked polyvinylpyrrolidones with increased affinity and specificity for methyl orange and its homologs. J. Polym. Sci. Polym. Chem. Ed. 1982, 20, 1533-1547. [CrossRef]

90. Sreenivasan, K. On the feasibility of using molecularly imprinted poly (Hema) as a sensor component. Talanta 1997, 44, 1137-1140 [CrossRef]

91. Alexander, C.; Andersson, H.S.; Andersson, L.I.; Ansell, R.J.; Kirsch, N.; Nicholls, I.A.; O'Mahony, J.; Whitcombe, M.J. Molecular imprinting science and technology: A survey of the literature for the years up to and including 2003. J. Mol. Recognit. Interdiscip. J. 2006, 19, 106-180. [CrossRef]

92. Svenson, J.; Karlsson, J.G.; Nicholls, I.A. 1H nuclear magnetic resonance study of the molecular imprinting of (-)-nicotine: Template self-association, a molecular basis for cooperative ligand binding. J. Chromatogr. A 2004, 1024, 39-44. [CrossRef]

93. Ekberg, B.; Mosbach, K. Molecular imprinting: A technique for producing specific separation materials. Trends Biotechnol. 1989, 7 , 92-96. [CrossRef]

94. Whitcombe, M.J.; Rodriguez, M.E.; Villar, P.; Vulfson, E.N. A new method for the introduction of recognition site functionality into polymers prepared by molecular imprinting: Synthesis and characterization of polymeric receptors for cholesterol. J. Am. Chem. Soc. 1995, 117, 7105-7111. [CrossRef]

95. Sellergren, B.; Allender, C.J. Molecularly imprinted polymers: A bridge to advanced drug delivery. Adv. Drug Deliv. Rev. 2005, 57, 1733-1741. [CrossRef] [PubMed]

96. Zahedi, P.; Ziaee, M.; Abdouss, M.; Farazin, A.; Mizaikoff, B. Biomacromolecule template-based molecularly imprinted polymers with an emphasis on their synthesis strategies: A review. Polym. Adv. Technol. 2016, 27, 1124-1142. [CrossRef]

97. Ding, S.; Lyu, Z.; Niu, X.; Zhou, Y.; Liu, D.; Falahati, M.; Du, D.; Lin, Y. Integrating ionic liquids with molecular imprinting technology for biorecognition and biosensing: A review. Biosens. Bioelectron. 2020, 149, 111830. [CrossRef] [PubMed]

98. Beyazit, S.; Bui, B.T.S.; Haupt, K.; Gonzato, C. Molecularly imprinted polymer nanomaterials and nanocomposites by controlled/living radical polymerization. Prog. Polym. Sci. 2016, 62, 1-21. [CrossRef]

99. Adali-Kaya, Z.; Tse Sum Bui, B.; Falcimaigne-Cordin, A.; Haupt, K. Molecularly imprinted polymer nanomaterials and nanocomposites: Atom-transfer radical polymerization with acidic monomers. Angew. Chem. 2015, 127, 5281-5284. [CrossRef]

100. Pan, G.; Zu, B.; Guo, X.; Zhang, Y.; Li, C.; Zhang, H. Preparation of molecularly imprinted polymer microspheres via reversible addition-fragmentation chain transfer precipitation polymerization. Polymers 2009, 50, 2819-2825. [CrossRef] 
101. Boonpangrak, S.; Whitcombe, M.J.; Prachayasittikul, V.; Mosbach, K.; Ye, L. Preparation of molecularly imprinted polymers using nitroxide-mediated living radical polymerization. Biosens. Bioelectron. 2006, 22, 349-354. [CrossRef]

102. Vaughan, A.D.; Sizemore, S.P.; Byrne, M.E. Enhancing molecularly imprinted polymer binding properties via controlled/living radical polymerization and reaction analysis. Polymers 2007, 48, 74-81. [CrossRef]

103. Refaat, D.; Aggour, M.G.; Farghali, A.A.; Mahajan, R.; Wiklander, J.G.; Nicholls, I.A.; Piletsky, S.A. Strategies for molecular imprinting and the evolution of MIP nanoparticles as plastic antibodies-Synthesis and applications. Int. J. Mol. Sci. 2019, 20, 6304. [CrossRef]

104. Hoshino, Y.; Shea, K.J. The evolution of plastic antibodies. J. Mater. Chem. 2011, 21, 3517-3521. [CrossRef]

105. Wulff, G. Fourty years of molecular imprinting in synthetic polymers: Origin, features and perspectives. Microchim. Acta 2013, 180, 1359-1370. [CrossRef]

106. Poma, A.; Turner, A.P.; Piletsky, S.A. Advances in the manufacture of MIP nanoparticles. Trends Biotechnol. 2010, $28,629-637$. [PubMed]

107. Ye, L.; Cormack, P.A.; Mosbach, K. Molecularly imprinted monodisperse microspheres for competitive radioassay. Anal. Commun. 1999, 36, 35-38. [CrossRef]

108. Jing, T.; Gao, X.-D.; Wang, P.; Wang, Y.; Lin, Y.-F.; Hu, X.-Z.; Hao, Q.-L.; Zhou, Y.-K.; Mei, S.-R. Determination of trace tetracycline antibiotics in foodstuffs by liquid chromatography-Tandem mass spectrometry coupled with selective molecular-imprinted solid-phase extraction. Anal. Bioanal. Chem. 2009, 393, 2009-2018. [CrossRef]

109. Vasapollo, G.; Sole, R.D.; Mergola, L.; Lazzoi, M.R.; Scardino, A.; Scorrano, S.; Mele, G. Molecularly imprinted polymers: Present and future prospective. Int. J. Mol. Sci. 2011, 12, 5908-5945. [CrossRef]

110. Chen, L.; Wang, X.; Lu, W.; Wu, X.; Li, J. Molecular imprinting: Perspectives and applications. Chem. Soc. Rev. 2016, 45, $2137-2211$. [CrossRef]

111. Vaihinger, D.; Landfester, K.; Kräuter, I.; Brunner, H.; Tovar, G.E. Molecularly imprinted polymer nanospheres as synthetic affinity receptors obtained by miniemulsion polymerisation. Macromol. Chem. Phys. 2002, 203, 1965-1973. [CrossRef]

112. Zhao, G.; Liu, J.; Liu, M.; Han, X.; Peng, Y.; Tian, X.; Liu, J.; Zhang, S. Synthesis of molecularly imprinted polymer via emulsion polymerization for application in solanesol separation. Appl. Sci. 2020, 10, 2868. [CrossRef]

113. Marchyk, N.; Maximilien, J.; Beyazit, S.; Haupt, K.; Bui, B.T.S. One-pot synthesis of iniferter-bound polystyrene core nanoparticles for the controlled grafting of multilayer shells. Nanoscale 2014, 6, 2872-2878. [CrossRef]

114. Shinde, S.; El-Schich, Z.; Malakpour, A.; Wan, W.; Dizeyi, N.; Mohammadi, R.; Rurack, K.; Gjörloff Wingren, A.; Sellergren, B Sialic acid-imprinted fluorescent core-shell particles for selective labeling of cell surface glycans. J. Am. Chem. Soc. 2015, 137, 13908-13912. [CrossRef] [PubMed]

115. Gonzato, C.; Courty, M.; Pasetto, P.; Haupt, K. Magnetic molecularly imprinted polymer nanocomposites via surface-initiated RAFT polymerization. Adv. Funct. Mater. 2011, 21, 3947-3953. [CrossRef]

116. Wan, L.; Chen, Z.; Huang, C.; Shen, X. Core-shell molecularly imprinted particles. TrAC Trends Anal. Chem. 2017, 95, 110-121. [CrossRef]

117. Markose, K.K.; Anjana, R.; Jayaraj, M. Upconversion Nanophosphors: An Overview. In Nanostructured Met. Oxides Devices; Jayaraj, M.K., Ed.; Springer: Berlin, Germany, 2020; pp. 47-102.

118. Zhang, Y.; Li, S.; Ma, X.-T.; He, X.-W.; Li, W.-Y.; Zhang, Y.-K. Carbon dots-embedded epitope imprinted polymer for targeted fluorescence imaging of cervical cancer via recognition of epidermal growth factor receptor. Microchim. Acta 2020, $187,1-11$. [CrossRef] [PubMed]

119. Yin, D.; Li, X.; Ma, Y.; Liu, Z. Targeted cancer imaging and photothermal therapy via monosaccharide-imprinted gold nanorods. Chem. Commun. 2017, 53, 6716-6719. [CrossRef] [PubMed]

120. Canfarotta, F.; Cecchini, A.; Piletsky, S. Nano-sized Molecularly Imprinted Polymers as Artificial Antibodies. In Molecularly Imprinted Polymers for Analytical Chemistry Applications; Royal Society of Chemistry: London, UK, 2018.

121. Poma, A.; Guerreiro, A.; Whitcombe, M.J.; Piletska, E.V.; Turner, A.P.; Piletsky, S.A. Solid-phase synthesis of molecularly imprinted polymer nanoparticles with a reusable template-“Plastic Antibodies". Adv. Funct. Mater. 2013, 23, 2821-2827. [CrossRef]

122. Canfarotta, F.; Poma, A.; Guerreiro, A.; Piletsky, S. Solid-phase synthesis of molecularly imprinted nanoparticles. Nat. Protoc. 2016, 11, 443-455. [CrossRef]

123. Biffis, A.; Graham, N.B.; Siedlaczek, G.; Stalberg, S.; Wulff, G. The synthesis, characterization and molecular recognition properties of imprinted microgels. Macromol. Chem. Phys. 2001, 202, 163-171. [CrossRef]

124. Çakir, P.; Cutivet, A.; Resmini, M.; Bui, B.T.S.; Haupt, K. Protein-size molecularly imprinted polymer nanogels as synthetic antibodies, by localized polymerization with multi-initiators. Adv. Mater. 2013, 25, 1048-1051. [CrossRef]

125. Wang, S.; Yin, D.; Wang, W.; Shen, X.; Zhu, J.-J.; Chen, H.-Y.; Liu, Z. Targeting and imaging of cancer cells via monosaccharideimprinted fluorescent nanoparticles. Sci. Rep. 2016, 6, 22757. [CrossRef]

126. Tian, L.; Guo, H.; Li, J.; Yan, L.; Zhu, E.; Liu, X.; Li, K. Fabrication of a near-infrared excitation surface molecular imprinting ratiometric fluorescent probe for sensitive and rapid detecting perfluorooctane sulfonate in complex matrix. J. Hazard. Mater. 2021, 413, 125353. [CrossRef] [PubMed]

127. Titirici, M.M.; Hall, A.J.; Sellergren, B. Hierarchical imprinting using crude solid phase peptide synthesis products as templates. Chem. Mater. 2003, 15, 822-824. [CrossRef] 
128. Xu, J.; Ambrosini, S.; Tamahkar, E.; Rossi, C.; Haupt, K.; Tse Sum Bui, B. Toward a universal method for preparing molecularly imprinted polymer nanoparticles with antibody-like affinity for proteins. Biomacromolecules 2016, 17, 345-353. [CrossRef] [PubMed]

129. Fresco-Cala, B.; Mizaikoff, B. Surrogate Imprinting Strategies: Molecular Imprints via Fragments and Dummies. ACS Appl. Polym. Mater. 2020, 2, 3714-3741. [CrossRef]

130. Yixiao, W.; Jinhua, L.; Liyan, W.; Ji, Q.; Lingxin, C. Recent advances in applications of fragment/dummy molecularly imprinted polymers. Chin. J. Chromatogr. 2021, 39, 134.

131. Takeuchi, T.; Sunayama, H. Beyond natural antibodies-A new generation of synthetic antibodies created by post-imprinting modification of molecularly imprinted polymers. Chem. Commun. 2018, 54, 6243-6251. [CrossRef]

132. Mattiasson, B.; Ye, L. Molecularly Imprinted Polymers in Biotechnology; Springer: Berlin/Heidelberg, Germany, $2015 ;$ Volume 150.

133. Linares, E.M.; Pannuti, C.S.; Kubota, L.T.; Thalhammer, S. Immunospot assay based on fluorescent nanoparticles for Dengue fever detection. Biosens. Bioelectron. 2013, 41, 180-185. [CrossRef]

134. Saeki, T.; Takano, E.; Sunayama, H.; Kamon, Y.; Horikawa, R.; Kitayama, Y.; Takeuchi, T. Signalling molecular recognition nanocavities with multiple functional groups prepared by molecular imprinting and sequential post-imprinting modifications for prostate cancer biomarker glycoprotein detection. J. Mater. Chem. B 2020, 8, 7987-7993. [CrossRef]

135. Sunayama, H.; Ooya, T.; Takeuchi, T. Fluorescent protein-imprinted polymers capable of signal transduction of specific binding events prepared by a site-directed two-step post-imprinting modification. Chem. Commun. 2014, 50, 1347-1349. [CrossRef]

136. Haupt, K.; Dzgoev, A.; Mosbach, K. Assay system for the herbicide 2, 4-dichlorophenoxyacetic acid using a molecularly imprinted polymer as an artificial recognition element. Anal. Chem. 1998, 70, 628-631. [CrossRef]

137. Chianella, I.; Guerreiro, A.; Moczko, E.; Caygill, J.S.; Piletska, E.V.; De Vargas Sansalvador, I.M.P.; Whitcombe, M.J.; Piletsky, S.A. Direct Replacement of Antibodies with Molecularly Imprinted Polymer Nanoparticles in ELISA Development of a Novel Assay for Vancomycin. Anal. Chem. 2013, 85, 8462-8468. [CrossRef] [PubMed]

138. Tang, S.-P.; Canfarotta, F.; Smolinska-Kempisty, K.; Piletska, E.; Guerreiro, A.; Piletsky, S. A pseudo-ELISA based on molecularly imprinted nanoparticles for detection of gentamicin in real samples. Anal. Methods 2017, 9, 2853-2858. [CrossRef]

139. Garcia, Y.; Smolinska-Kempisty, K.; Pereira, E.; Piletska, E.; Piletsky, S. Development of competitive 'pseudo'-ELISA assay for measurement of cocaine and its metabolites using molecularly imprinted polymer nanoparticles. Anal. Methods 2017, 9, 4592-4598. [CrossRef]

140. Jia, M.; Chen, S.; Shi, T.; Li, C.; Wang, Y.; Zhang, H. Competitive plasmonic biomimetic enzyme-linked immunosorbent assay for sensitive detection of bisphenol A. Food Chem. 2021, 344, 128602. [CrossRef] [PubMed]

141. Abd El-Aal, M.A.; Al-Ghobashy, M.A.; El-Saharty, Y.S. Preparation and characterization of 96-well microplates coated with molecularly imprinted polymer for determination and biosimilarity assessment of recombinant human erythropoietin. $J$. Chromatogr. A 2021, 1641, 462012. [CrossRef]

142. Guoning, C.; Hua, S.; Wang, L.; Qianqian, H.; Xia, C.; Hongge, Z.; Zhimin, L.; Chun, C.; Qiang, F. A surfactant-mediated sol-gel method for the preparation of molecularly imprinted polymers and its application in a biomimetic immunoassay for the detection of protein. J. Pharm. Biomed. Anal. 2020, 190, 113511. [CrossRef]

143. Piletska, E.V.; Piletsky, S.S.; Guerreiro, A.; Karim, K.; Whitcombe, M.J.; Piletsky, S.A. Microplates with enhanced immobilization capabilities controlled by a magnetic field. J. Chin. Adv. Mater. Soc. 2014, 2, 118-129. [CrossRef]

144. Piletsky, S.; Rabinowicz, S.; Yang, Z.; Zagar, C.; Piletska, E.V.; Guerreiro, A.; Piletsky, S.A. Development of molecularly imprinted polymers specific for blood antigens for application in antibody-free blood typing. Chem. Commun. 2017, 53, 1793-1796. [CrossRef]

145. Piletsky, S.S.; Cass, A.E.; Piletska, E.V.; Czulak, J.; Piletsky, S.A. A novel assay format as an alternative to ELISA: MINA test for biotin. ChemNanoMat 2018, 4, 1214-1222. [CrossRef]

146. Esen, C.; Czulak, J.; Cowen, T.; Piletska, E.; Piletsky, S.A. Highly efficient abiotic assay formats for methyl parathion: Molecularly imprinted polymer nanoparticle assay as an alternative to enzyme-linked immunosorbent assay. Anal. Chem. 2018, 91, 958-964 [CrossRef]

147. Mahajan, R.; Rouhi, M.; Shinde, S.; Bedwell, T.; Incel, A.; Mavliutova, L.; Piletsky, S.; Nicholls, I.A.; Sellergren, B. Highly Efficient Synthesis and Assay of Protein-Imprinted Nanogels by Using Magnetic Templates. Angew. Chem. 2019, 131, 737-740. [CrossRef]

148. Garcia-Cruz, A.; Cowen, T.; Voorhaar, A.; Piletska, E.; Piletsky, S.A. Molecularly imprinted nanoparticles-based assay (MINA)Detection of leukotrienes and insulin. Analyst 2020, 145, 4224-4232. [CrossRef] [PubMed]

149. Li, Y.; Liu, Y.; Liu, J.; Liu, J.; Tang, H.; Cao, C.; Zhao, D.; Ding, Y. Molecularly imprinted polymer decorated nanoporous gold for highly selective and sensitive electrochemical sensors. Sci. Rep. 2015, 5, 7699. [CrossRef]

150. Piletsky, S.A.; Piletska, E.V.; Chen, B.; Karim, K.; Weston, D.; Barrett, G.; Lowe, P.; Turner, A.P. Chemical grafting of molecularly imprinted homopolymers to the surface of microplates. Application of artificial adrenergic receptor in enzyme-linked assay for $\beta$-agonists determination. Anal. Chem. 2000, 72, 4381-4385. [CrossRef] [PubMed]

151. Perçin, I.; Idil, N.; Bakhshpour, M.; Yılmaz, E.; Mattiasson, B.; Denizli, A. Microcontact imprinted plasmonic nanosensors: Powerful tools in the detection of salmonella paratyphi. Sensors 2017, 17, 1375. [CrossRef] [PubMed]

152. Dickert, F.L.; Hayden, O.; Bindeus, R.; Mann, K.-J.; Blaas, D.; Waigmann, E. Bioimprinted QCM sensors for virus detection-Screening of plant sap. Anal. Bioanal. Chem. 2004, 378, 1929-1934. [CrossRef]

153. Schirhagl, R.; Lieberzeit, P.A.; Dickert, F.L. Chemosensors for viruses based on artificial immunoglobulin copies. Adv. Mater. 2010, 22, 2078-2081. [CrossRef] 
154. Li, W.; Diao, K.; Qiu, D.; Zeng, Y.; Tang, K.; Zhu, Y.; Sheng, Y.; Wen, Y.; Li, M. A highly-sensitive and selective antibody-like sensor based on molecularly imprinted poly (L-arginine) on $\mathrm{COOH}-\mathrm{MWCNT}$ for electrochemical recognition and detection of deoxynivalenol. Food Chem. 2021, 350, 129229. [CrossRef]

155. Raziq, A.; Kidakova, A.; Boroznjak, R.; Reut, J.; Öpik, A.; Syritski, V. Development of a portable MIP-based electrochemical sensor for detection of SARS-CoV-2 antigen. Biosens. Bioelectron. 2021, 178, 113029. [CrossRef]

156. You, M.; Yang, S.; An, Y.; Zhang, F.; He, P. A novel electrochemical biosensor with molecularly imprinted polymers and aptamer-based sandwich assay for determining amyloid- $\beta$ oligomer. J. Electroanal. Chem. 2020, 862, 114017. [CrossRef]

157. Carneiro, L.P.; Ferreira, N.S.; Tavares, A.P.; Pinto, A.M.; Mendes, A.; Sales, M.G.F. A passive direct methanol fuel cell as transducer of an electrochemical sensor, applied to the detection of carcinoembryonic antigen. Biosens. Bioelectron. $2021,175,112877$. [CrossRef] [PubMed]

158. Duan, L.; Zhao, Y. Molecularly imprinted micelles for fluorescent sensing of nonsteroidal anti-inflammatory drugs (NSAIDs). React. Funct. Polym. 2021, 158, 104759. [CrossRef] [PubMed]

159. Chapman, S.; Dobrovolskaia, M.; Farahani, K.; Goodwin, A.; Joshi, A.; Lee, H.; Meade, T.; Pomper, M.; Ptak, K.; Rao, J. Nanoparticles for cancer imaging: The good, the bad, and the promise. Nano Today 2013, 8, 454-460. [CrossRef] [PubMed]

160. Canfarotta, F.; Waters, A.; Sadler, R.; McGill, P.; Guerreiro, A.; Papkovsky, D.; Haupt, K.; Piletsky, S. Biocompatibility and internalization of molecularly imprinted nanoparticles. Nano Res. 2016, 9, 3463-3477. [CrossRef]

161. Hayakawa, N.; Yamada, T.; Kitayama, Y.; Takeuchi, T. Cellular Interaction Regulation by Protein Corona Control of Molecularly Imprinted Polymer Nanogels Using Intrinsic Proteins. ACS Appl. Polym. Mater. 2020, 2, 1465-1473. [CrossRef]

162. Ghazarian, H.; Idoni, B.; Oppenheimer, S.B. A glycobiology review: Carbohydrates, lectins and implications in cancer therapeutics. Acta Histochem. 2011, 113, 236-247. [CrossRef]

163. Lin, C.I.; Joseph, A.K.; Chang, C.K.; Der Lee, Y. Molecularly imprinted polymeric film on semiconductor nanoparticles: Analyte detection by quantum dot photoluminescence. J. Chromatogr. A 2004, 1027, 259-262. [CrossRef]

164. Liu, R.; Guan, G.; Wang, S.; Zhang, Z. Core-shell nanostructured molecular imprinting fluorescent chemosensor for selective detection of atrazine herbicide. Analyst 2011, 136, 184-190. [CrossRef]

165. Kunath, S.; Panagiotopoulou, M.; Maximilien, J.; Marchyk, N.; Sänger, J.; Haupt, K. Cell and tissue imaging with molecularly imprinted polymers as plastic antibody mimics. Adv. Healthc. Mater. 2015, 4, 1322-1326. [CrossRef]

166. Panagiotopoulou, M.; Salinas, Y.; Beyazit, S.; Kunath, S.; Duma, L.; Prost, E.; Mayes, A.G.; Resmini, M.; Tse Sum Bui, B.; Haupt, K. Molecularly imprinted polymer coated quantum dots for multiplexed cell targeting and imaging. Angew. Chem. 2016, 128, 8384-8388. [CrossRef]

167. Demir, B.; Lemberger, M.M.; Panagiotopoulou, M.; Medina Rangel, P.X.; Timur, S.; Hirsch, T.; Tse Sum Bui, B.; Wegener, J.; Haupt, K. Tracking hyaluronan: Molecularly imprinted polymer coated carbon dots for cancer cell targeting and imaging. ACS Appl. Mater. Interfaces 2018, 10, 3305-3313. [CrossRef] [PubMed]

168. Rangel, P.X.M.; Laclef, S.; Xu, J.; Panagiotopoulou, M.; Kovensky, J.; Bui, B.T.S.; Haupt, K. Solid-phase synthesis of molecularly imprinted polymer nanolabels: Affinity tools for cellular bioimaging of glycans. Sci. Rep. 2019, 9, 3923. [CrossRef] [PubMed]

169. Wang, S.; Wen, Y.; Wang, Y.; Ma, Y.; Liu, Z. Pattern recognition of cells via multiplexed imaging with monosaccharide-imprinted quantum dots. Anal. Chem. 2017, 89, 5646-5652. [CrossRef] [PubMed]

170. Puoci, F.; Cirillo, G.; Curcio, M.; Iemma, F.; Parisi, O.I.; Castiglione, M.; Picci, N. Molecularly imprinted polymers for $\alpha$-tocopherol delivery. Drug Deliv. 2008, 15, 253-258. [CrossRef]

171. Cirillo, G.; Parisi, O.I.; Curcio, M.; Puoci, F.; Iemma, F.; Spizzirri, U.G.; Picci, N. Molecularly imprinted polymers as drug delivery systems for the sustained release of glycyrrhizic acid. J. Pharm. Pharmacol. 2010, 62, 577-582. [CrossRef]

172. Curcio, M.; Cirillo, G.; Parisi, O.I.; Iemma, F.; Picci, N.; Puoci, F. Quercetin-imprinted nanospheres as novel drug delivery devices. J. Funct. Biomater. 2012, 3, 269-282. [CrossRef]

173. Parisi, O.I.; Morelli, C.; Puoci, F.; Saturnino, C.; Caruso, A.; Sisci, D.; Trombino, G.E.; Picci, N.; Sinicropi, M.S. Magnetic molecularly imprinted polymers (MMIPs) for carbazole derivative release in targeted cancer therapy. J. Mater. Chem. B 2014, 2, 6619-6625. [CrossRef]

174. Liu, R.; Poma, A. Advances in Molecularly Imprinted Polymers as Drug Delivery Systems. Molecules 2021, 26, 3589. [CrossRef]

175. Hashemi-Moghaddam, H.; Zavareh, S.; Karimpour, S.; Madanchi, H. Evaluation of molecularly imprinted polymer based on HER2 epitope for targeted drug delivery in ovarian cancer mouse model. React. Funct. Polym. 2017, 121, 82-90. [CrossRef]

176. Canfarotta, F.; Lezina, L.; Guerreiro, A.; Czulak, J.; Petukhov, A.; Daks, A.; Smolinska-Kempisty, K.; Poma, A.; Piletsky, S.; Barlev, N.A. Specific drug delivery to cancer cells with double-imprinted nanoparticles against epidermal growth factor receptor. Nano Lett. 2018, 18, 4641-4646. [CrossRef]

177. Hoshino, Y.; Koide, H.; Urakami, T.; Kanazawa, H.; Kodama, T.; Oku, N.; Shea, K.J. Recognition, neutralization, and clearance of target peptides in the bloodstream of living mice by molecularly imprinted polymer nanoparticles: A plastic antibody. J. Am. Chem. Soc. 2010, 132, 6644-6645. [CrossRef] [PubMed]

178. Kiessling, F.; Mertens, M.E.; Grimm, J.; Lammers, T. Nanoparticles for imaging: Top or flop? Radiology 2014, 273, 10-28. [CrossRef] [PubMed]

179. Jeanes, A.; Gottardi, C.; Yap, A. Cadherins and cancer: How does cadherin dysfunction promote tumor progression? Oncogene 2008, 27, 6920-6929. [CrossRef] [PubMed] 
180. Medina Rangel, P.X.; Moroni, E.; Merlier, F.; Gheber, L.A.; Vago, R.; Tse Sum Bui, B.; Haupt, K. Chemical Antibody Mimics Inhibit Cadherin-Mediated Cell-Cell Adhesion: A Promising Strategy for Cancer Therapy. Angew. Chem. Int. Ed. 2020, 59, 2816-2822. [CrossRef] [PubMed]

181. Ishikawa, T.; Ichikawa, Y.; Shimizu, D.; Sasaki, T.; Tanabe, M.; Chishima, T.; Takabe, K.; Endo, I. The role of HER-2 in Breast Cancer. J. Surg. Sci. 2014, 2, 4.

182. Dong, Y.; Li, W.; Gu, Z.; Xing, R.; Ma, Y.; Zhang, Q.; Liu, Z. Inhibition of HER2-positive breast cancer growth by blocking the HER2 signaling pathway with HER2-glycan-imprinted nanoparticles. Angew. Chem. Int. Ed. 2019, 58, 10621-10625. [CrossRef]

183. Parisi, O.I.; Dattilo, M.; Patitucci, F.; Malivindi, R.; Delbue, S.; Ferrante, P.; Parapini, S.; Galeazzi, R.; Cavarelli, M.; Cilurzo, F. Design and development of plastic antibodies against SARS-CoV-2 RBD based on molecularly imprinted polymers that inhibit in vitro virus infection. Nanoscale 2021, 13, 16885-16899. [CrossRef]

184. Wu, C.; Liu, Y.; Yang, Y.; Zhang, P.; Zhong, W.; Wang, Y.; Wang, Q.; Xu, Y.; Li, M.; Li, X. Analysis of therapeutic targets for SARS-CoV-2 and discovery of potential drugs by computational methods. Acta Pharm. Sin. B 2020, 10, 766-788. [CrossRef]

185. Thakor, A.S.; Jokerst, J.V.; Ghanouni, P.; Campbell, J.L.; Mittra, E.; Gambhir, S.S. Clinically approved nanoparticle imaging agents. J. Nucl. Med. 2016, 57, 1833-1837. [CrossRef]

186. Anselmo, A.C.; Mitragotri, S. Nanoparticles in the clinic. Bioeng. Transl. Med. 2016, 1, 10-29. [CrossRef]

187. Wang, H.-Y.; Cao, P.-P.; He, Z.-Y.; He, X.-W.; Li, W.-Y.; Li, Y.-H.; Zhang, Y.-K. Targeted imaging and targeted therapy of breast cancer cells via fluorescent double template-imprinted polymer coated silicon nanoparticles by an epitope approach. Nanoscale 2019, 11, 17018-17030. [CrossRef] [PubMed]

188. Jia, C.; Zhang, M.; Zhang, Y.; Ma, Z.-B.; Xiao, N.-N.; He, X.-W.; Li, W.-Y.; Zhang, Y.-K. Preparation of dual-template epitope imprinted polymers for targeted fluorescence imaging and targeted drug delivery to pancreatic cancer BxPC-3 cells. ACS Appl. Mater. Interfaces 2019, 11, 32431-32440. [CrossRef] [PubMed]

189. Qin, Y.-T.; Peng, H.; He, X.-W.; Li, W.-Y.; Zhang, Y.-K. Highly effective drug delivery and cell imaging using fluorescent doubleimprinted nanoparticles by targeting recognition of the epitope of membrane protein. Anal. Chem. 2019, 91, 12696-12703. [CrossRef]

190. Zhu, Y.; Liu, R.; Huang, H.; Zhu, Q. Vinblastine-loaded nanoparticles with enhanced tumor-targeting efficiency and decreasing toxicity: Developed by one-step molecular imprinting process. Mol. Pharm. 2019, 16, 2675-2689. [CrossRef] [PubMed]

191. Owens III, D.E.; Peppas, N.A. Opsonization, biodistribution, and pharmacokinetics of polymeric nanoparticles. Int. J. Pharm. 2006, 307, 93-102. [CrossRef] [PubMed]

192. Takeuchi, T.; Kitayama, Y.; Sasao, R.; Yamada, T.; Toh, K.; Matsumoto, Y.; Kataoka, K. Molecularly imprinted nanogels acquire stealth in situ by cloaking themselves with native dysopsonic proteins. Angew. Chem. 2017, 129, 7194-7198. [CrossRef]

193. Yoshida, A.; Kitayama, Y.; Kiguchi, K.; Yamada, T.; Akasaka, H.; Sasaki, R.; Takeuchi, T. Gold nanoparticle-incorporated molecularly imprinted microgels as radiation sensitizers in pancreatic cancer. ACS Appl. Bio Mater. 2019, 2, 1177-1183. [CrossRef]

194. Huang, X.; El-Sayed, I.H.; Qian, W.; El-Sayed, M.A. Cancer cell imaging and photothermal therapy in the near-infrared region by using gold nanorods. J. Am. Chem. Soc. 2006, 128, 2115-2120. [CrossRef]

195. Zhang, Y.; Deng, C.; Liu, S.; Wu, J.; Chen, Z.; Li, C.; Lu, W. Active targeting of tumors through conformational epitope imprinting. Angew. Chem. 2015, 127, 5246-5249. [CrossRef]

196. Liu, S.; Bi, Q.; Long, Y.; Li, Z.; Bhattacharyya, S.; Li, C. Inducible epitope imprinting:'generating'the required binding site in membrane receptors for targeted drug delivery. Nanoscale 2017, 9, 5394-5397. [CrossRef]

197. Peng, S.; Wang, Y.; Li, N.; Li, C. Enhanced cellular uptake and tumor penetration of nanoparticles by imprinting the "hidden" part of membrane receptors for targeted drug delivery. Chem. Commun. 2017, 53, 11114-11117. [CrossRef] [PubMed]

198. Parisi, O.I.; Ruffo, M.; Malivindi, R.; Vattimo, A.F.; Pezzi, V.; Puoci, F. Molecularly imprinted polymers (MIPs) as theranostic systems for sunitinib controlled release and self-monitoring in cancer therapy. Pharmaceutics 2020, 12, 41. [CrossRef] [PubMed] 